\title{
"Retreat to the Boundary of the Rules": Resurrecting Professionalism in Depositions and the Implications of Gamesmanship for Kansas Practitioners
}

\author{
Matthew Rogers* and Suzanne Valdez**
}

\section{INTRODUCTION}

"Something is rotten, but contrary to Marcellus's suggestion to

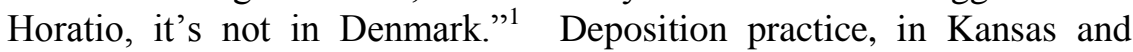
elsewhere, plays an important role that generally facilitates early and less-expensive resolution of disputes. ${ }^{2}$ As one of the most essential elements of discovery, depositions are intended to enable the free flow of information between the parties. ${ }^{3}$ The reality that more than ninety percent of civil cases filed in both federal and state courts are resolved outside the courtroom highlights the tremendous importance that factfinding depositions serve. ${ }^{4}$ This not-so-new reality is the fuel that fires many discovery disputes and hampers the flow of information-"now

\footnotetext{
* J.D. 2016, University of Kansas School of Law; B.A. Criminal Justice 2006, MidAmerica Nazarene University. Thank you to Professor Todd Hiestand for suggesting law school and your guidance along the way. Thank you to my wife, Leslie. You have always been by my side, supporting me as I embark on a new career and supporting our family when I am burning the midnight oil. Finally, thank you to my children, Tanner, Landon, and our yet-to-be-born son, for understanding when dad is busy with "work" and providing some much-needed comic relief!

**J.D. 1996, University of Kansas School of Law; B.S. 1991, University of Nevada, Las Vegas. Clinical Professor of Law and Director of the Criminal Prosecution Clinic at the University of Kansas School of Law. Professor Valdez teaches Professional Responsibility and upper-level practical skills courses, which include Practice in Kansas, Pretrial Advocacy, and the Deposition Skills Workshop.

1. Sec. Nat'l Bank of Sioux City, Iowa v. Abbott Labs., 299 F.R.D. 595, 596 (N.D. Iowa 2014), rev'd on other grounds, Sec. Nat'l Bank of Sioux City, Iowa v. Jones Day, 800 F.3d 936, 944-45 (8th Cir. 2015) (reversing because the district court failed to give sufficient notice of unusual sanction).

2. David Malone \& Peter Hoffman, The Effective Deposition: Techniques and STRATEGIES THAT WORK xxiii-xxiv (4th ed. 2012).

3. See Abbott Labs., 299 F.R.D. at 596.

4. See GMAC Bank v. HTFC Corp., 248 F.R.D. 182, 185 (E.D. Pa. 2008) (citing Admin. Office of the U.S. Courts, Judicial Business of the United States Courts: 2006, Table C-4A).
} 
too often mired in obstructionism [in depositions]."5 Whatever the reason, whether to grandstand for a client or to win the litigation war, obstructionist litigators' warped view of zealous advocacy only serves to deny "the just, speedy, and inexpensive determination of every action and proceeding." 6 As the old saying goes: the wheels of justice turn slowly. So too have the courts' wheels been slow to "stop reinforcing winning through obstruction."7

Most litigators conduct depositions in a professional and courteous demeanor. A chosen few, however, select a different route. Like "Ivan Pavlov's dogs," these practitioners salivate at any opportunity to impede the flow of information in depositions. ${ }^{8}$ Some are rewarded by a judiciary that too often ignores this conduct. ${ }^{9}$ As the tide shifts, however, obstructionist attorneys are exposed to a judiciary that appears to be fed up with the present state of deposition practice and with less hesitation to impose more severe sanctions. That is not to say that all jurisdictions are plagued with obstructionist behavior around every bend; to the contrary, many jurisdictions offer little case law guidance, particularly Kansas. However, a close examination of the federal and state procedural rules, ${ }^{10}$ the local federal practice guidelines, ${ }^{11}$ and the rules of professional conduct $^{12}$ provide instruction on how to conduct oneself when taking - or defending - any deposition.

The purpose of this Article is to provide guidance for litigators who conduct depositions, both by informing the reader what type of behavior is allowed under the rules and what constitutes sanctionable conduct. Although this Article may be particularly useful for attorneys practicing in Kansas state and federal courts, the conclusions drawn are relevant in any jurisdiction. In Part II.A., we briefly discuss the implications of vexatious scheduling tactics and how schemes to delay or manipulate the calendaring of depositions impedes the overall discovery timeline and frustrates a party's access to testimony from either the opposing party or other key witnesses in a civil case. Second, in Part II.B., this Article

5. See Abbott Labs., 299 F.R.D. at 596-97.

6. Id. at 596-97 (quoting FED. R. CIV. P. 1).

7. Id. at 597 .

8. Id.

9. Id.

10. FED. R. CIV. P. 30, 32

11. Deposition Guidelines, U.S. DisT. CT. FOR THE DIST. OF KAN., http://www.ksd.uscourts.gov/deposition-guidelines/ (last visited Apr. 25, 2016) [hereinafter Deposition Guidelines].

12. See infra Part II.F. 
analyzes numerous forms of obstreperous behavior and suggests how opposing counsel should respond. Additionally, this part considers the negative consequences such behavior can have on a practitioner's reputation and career. Third, in Part II.C., this Article closely examines forms of on-the-record witness coaching, speaking objections, and instructions not to answer. This part also discusses the "form" objection controversy and how to properly lodge such an objection in the District of Kansas. Fourth, in Part II.D., this Article contrasts proper forms of private conferences during depositions with improper off-the-record witness coaching. Fifth, in Part II.E., this Article highlights the need to remain vigilant post-deposition by studying the improper use of errata sheets to change material deposition testimony. Sixth, in Part II.F., we briefly discuss a court's power to sanction discovery misconduct under federal and state procedural rules, and the Kansas Rules of Professional Conduct that are implicated when a lawyer engages in gamesmanship tactics or misconduct that crosses ethical boundaries. Finally, in Part III, we offer a brief conclusion.

\section{ANALYSIS}

In delving into our discussion of the various forms of inappropriate behavior and questionable tactics that are the hallmark of misconduct in deposition practice, we attempt to analyze these matters through the lens of Kansas practice-both in the federal district court and Kansas state court. Thus, we analyze and interpret the pertinent Federal Rules of Civil Procedure and the United States District of Kansas local practice rules and Deposition Guidelines. Also, we use case law to help us interpret federal procedural rules and guidelines when it is appropriate and available to do so. With regard to Kansas state practice, to the extent the procedural rules are different and there is available interpretive case law, we try to highlight those differences too. Lastly, legal ethics, which include the Kansas Rules of Professional Conduct and the Kansas Pillars of Professionalism, play an important role in how all lawyers licensed in Kansas and practicing in either federal or state court should conduct themselves in discovery practice. So, to the extent ethical rules or the professionalism code is implicated in our discussion, we attempt to bring attention to them as well.

\section{A. Vexatious Scheduling}

The Federal Rules of Civil Procedure provide little guidance on the 
process of how parties should schedule depositions. Federal Rule 30(b) states that "[a] party who wants to depose a person... must give reasonable written notice to every other party." 13 However, this rule does not define what is meant by "reasonable written notice," nor does it suggest that the parties should discuss and coordinate scheduling matters so as to avoid any misunderstanding or conflict. ${ }^{14}$ Since Federal Rule 26(f)(1) states that the "parties must confer as soon as practicable" to conduct a discovery conference and draft a proposed scheduling order, arguably this "meet and greet" with lawyers should be used by the parties to discuss deposition practice, including discussing the witnesses who will be deposed and the timing of when the depositions are likely to occur in the discovery phase of the case. ${ }^{15}$

The District of Kansas Local Rule 30.1 and the federal court's Deposition Guidelines are both helpful, and yet somewhat inconsistent, in defining what is meant by "reasonable written notice" to be given for a deposition under Federal Rule 30(b). ${ }^{16}$ For example, Local Rule 30.1, explicitly provides that "reasonable notice provided by Fed. R. Civ. Pro. 30(b)(1) for the taking of depositions is 7 days." $" 17$ This local rule further states that "[f]or good cause, the court may enlarge or shorten such time." ${ }^{18}$ But note, the Deposition Guidelines, at paragraph three, provide:

[a]bsent extraordinary circumstances, counsel shall consult in advance with opposing counsel and proposed deponents in an effort to schedule depositions at mutually convenient times and places. That counsel for a party may be unavailable shall not, however, be grounds for postponing a deposition if another attorney of record for that party is able to attend. Unless leave of court or agreement of counsel is first obtained, at least five (5) calendar days' notice of any deposition shall be given. 19

Whether "reasonable written notice" for the taking of a deposition is seven days or five days, the Federal Rules relating to discovery and the Deposition Guidelines both require counsel to confer as soon as

13. FED. R. CIV. P. 30(b)(1).

14. See generally A. Darby Dickerson, Deposition Dilemmas: Vexatious Scheduling and Errata Sheets, 12 GEO. J. LEGAL ETHICS 1 (1998).

15. FED. R. CIV. P. 26(f).

16. FED. R. CIV. P. 30(b)(1).

17. D. KAN. R. § 30.1 [hereinafter Local Rule § 30.1].

18. Id.

19. Deposition Guidelines, supra note 11, If 3 (emphasis added). 
practicable about the scheduling of depositions for a case. Importantly, Local Rule 30.1 clearly provides that the seven-day window can be shortened to five days or even fewer days if good cause is shown to the court. $^{20}$

Another notable condition to scheduling depositions under the Federal Rules is that, under Federal Rule 30(d)(1), "a deposition is limited to 1 day of 7 hours," unless the parties agree or the court orders otherwise. ${ }^{21}$ Further this provision of Federal Rule 30 provides that the court "must allow additional time consistent with Rule 26(b)(1) and (2) if needed to fairly examine the deponent or if the deponent, another person, or any other circumstance impedes or delays the examination.",22

These instructions about how "reasonable written notice" is achieved under Federal Rule 30(b) and the time limitations under Federal Rule 30(d)(1) should be beneficial to avoid conflicts that arise in scheduling or rescheduling of depositions. One of the few cases in the federal courts addressing the issue of vexatious scheduling of depositions arose in the District of Kansas in 1997, well before the Deposition Guidelines were promulgated by the district court. In Oleson v. Kmart Corp. ${ }^{23}$ the defendant's counsel, Mr. Haynes, engaged in what the court described as "discourteous, disruptive and unprofessional" conduct in defending the depositions taken of his client's four employees. ${ }^{24}$ During the deposition of one employee, Mr. Haynes repeatedly instructed the deponentemployee "not to answer questions to which no privilege was asserted," he "argued objections," and he interrupted deposing counsel numerous times. ${ }^{25}$ When a second deposition of another employee on the same day got delayed well into the evening due mostly to Mr. Haynes's "unprofessional and unacceptable" conduct in the first deposition, deposing counsel asked that the second deposition be rescheduled. ${ }^{26} \mathrm{Mr}$. Haynes refused this request. ${ }^{27}$ In yet another deposition of defendant's employee taken later in the case, Mr. Haynes failed to timely turn over documents before the deposition, which had been properly requested by

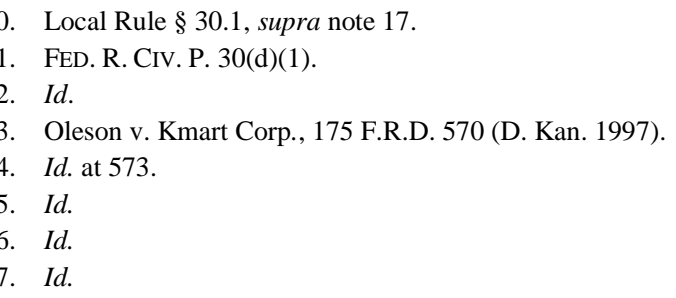


deposing counsel. ${ }^{28}$ Then, when deposing counsel requested to recess the deposition because of inclement weather and because of $\mathrm{Mr}$. Haynes's failure to produce documents needed for the deposition, Mr. Haynes refused. ${ }^{29}$ Frustrated with Mr. Haynes's overall conduct in the deposition, the district court imposed monetary sanctions directly upon him. ${ }^{30}$ Further, in referring to a deposition of an employee that would have started at 7:00 p.m. due to Mr. Haynes's misconduct, the court intimated that a deposition occurring after "normal business hours" would need the prior agreement of the parties to proceed. ${ }^{31}$

The Kansas state deposition rule, found at section 60-230(b) of the Kansas state code, mirrors the federal rule with regard to the "reasonable written notice" language in scheduling depositions. ${ }^{32}$ However, unlike the local federal rule that defines "reasonable written notice" to mean seven days, there is no counterpart in the state procedural rules. Further, unlike Federal Rule 30(d)(1), Kansas law does not have a time limit for a deposition to be completed, nor is there any statutory mandate that a discovery conference be held between the parties and their counsel to plan discovery or discuss deposition practice. ${ }^{33}$ In fact, because there is not a discreet discovery period under the state procedural rules, a deposition can be scheduled at any time after the Petition-the initial pleading - has been filed. Presumably, in the state system, a deposition can continue from day to day until it is completed. Finally, and significantly, there is no state counterpart to the federal district court's Deposition Guidelines, so state practitioners may be left to muddle through difficult or vexatious deposition scheduling tactics with much less guidance than is provided by the local federal district court.

\section{B. Incivility}

Too often counsel forget - or choose to ignore - that depositions are part of judicial proceedings and "not a playground or a boxing ring 
where one feels out his opponent." ${ }^{34}$ Because depositions are outside the immediate control of the judge, they can present a breeding ground for incivility and quickly deteriorate the purpose of any deposition: obtaining clear, truthful answers of the witnesses within the scope of discovery. ${ }^{35}$ Behavior of this sort hampers evidence collection and delays the judicial process. Incivility is not directly addressed in the Federal Rules, however an implicit component of Federal Rule 30 requires counsel to cooperate and be courteous to each other and to deponents. ${ }^{36}$ Further, the District of Kansas Deposition Guidelines explicitly note that "[c]ounsel are expected to cooperate with, and be courteous to, each other and deponents." 37 Although the state of Kansas has not adopted deposition guidelines, the Kansas Rules of Professional Conduct suggest that counsel conduct themselves with decorum and professionalism. $^{38}$

The federal and state procedural rules and deposition guidelines provide useful instruction, however they are broad enough to leave some ambiguity towards defining when the "incivility line" is breached. Often the very judge who reviews the deposition transcript may not be far removed from private practice and understands that " $[\mathrm{t}]$ here are times when comments and actions of counsel defending [or taking] a deposition, although technically inconsistent with the strict principles," can be helpful towards protecting the interests of their clients. ${ }^{39}$ Unfortunately, at both the federal and state levels, Kansas case law provides minimal guidance for practitioners when it comes to examples of incivility. A review of sanctionable conduct outside of Kansas's borders, however, shines some light on the type of conduct the Kansas courts should aim to discourage. The judicial tide is shifting, it seems, with a proactive eye towards curtailing abusive and discourteous deposition conduct. ${ }^{40}$

\footnotetext{
2005).

34. Heriaud v. Ryder Transp. Servs., No. 030289, 2005 WL 2230199, at *8 (N.D. Ill. Sept. 8,

35. Cincinnati Ins. Co. v. Serrano, No. 11-2075, 2012 WL 28071, at *6 (D. Kan. Jan. 5, 2012).

36. Ash Grove Cement Co. v. Wausau Ins. Co., No. 05-2339, 2007 WL 689576, at *3 (D. Kan. Mar. 1, 2007).

37. See Deposition Guidelines, supra note 11, I[ 1.

38. KAN. R. PROF'L CONDUCt 8.4(d) (“[i]t is professional misconduct for a lawyer to ... engage in conduct that is prejudicial to the administration of justice"); KAN. R. PROF'L CONDUCT 1.2 (noting that the lawyer controls the means); KAN. R. PROF'L CONDUCT 3.2 (requiring counsel to take reasonable efforts to expedite litigation); see infra Part II.F.

39. See Serrano, 2012 WL 28071, at *6.

40. See Sec. Nat'l Bank of Sioux City, Iowa v. Abbott Labs., 299 F.R.D. $595-97$ (N.D. Iowa 2014) (describing deposition conduct as "rotten" and noting that by ignoring such conduct, judges
} 


\section{Discreet Incivility-Gamesmanship}

Stepping outside the strict principles of deposition rules to protect the interests of one's client is tempered by an equally important instruction: "when ... counsel complains that such conduct is obstructing the deposition,... counsel are obliged to retreat to the boundaries of the rules." ${ }^{41}$ A useful deposition certainly requires preparation of working theories and testing those theories by employing a variety of questioning techniques. ${ }^{42}$ But deposition tactics that cross the line "between appropriately aggressive advocacy and unrestrained, pointless [gamesmanship]" will step outside the bounds of the rules. ${ }^{43}$ Even strategies that may seem minor and non-sanctionable can result in a deposition transcript that proves otherwise. ${ }^{44}$ For instance, in Huggins $v$. Coatesville Area School District, counsel was sanctioned after candidly admitting that he purposefully referred to the fact witness as "Ms. Walker" rather than "Dr. Walker" in an effort to make her feel "uneasy" and to "get an edge on [his] advocacy." 45 Similarly, practitioners should avoid attempts to gain the upper hand by delving into clearly irrelevant and sensitive topics, hostile comments designed to bait the deponent, or commentary such as "I'm asking the questions."46 Gamesmanship comes in many forms, including direct efforts to glean information from opposing counsel's material. In Leo v. Garmin International, Inc., pro se

"reinforce- even incentivize-obstructionist tactics"), rev'd on other grounds, Sec. Nat'l Bank of Sioux City, Iowa v. Jones Day, 800 F.3d 936, 944-45 (8th Cir. 2015) (reversing because the district court failed to give sufficient notice of unusual sanction).

41. Serrano, $2012 \mathrm{WL} 28071$, at $* 6$.

42. MALONE \& HOFFMAN, supra note 2, at 71-74, 133-51.

43. Huggins v. Coatesville Area Sch. Dist., No. 07-4917, 2009 WL 2973044, at*1 (E.D. Pa. Sept. 16, 2009).

44. See Corsini v. U-Haul Int'l, 212 A.D.2d 288, 289 (N.Y. App. Div. 1995) (while not sanctionable, noting the harassing behavior prior to a deposition where plaintiff counsel followed "defense counsel about the hallways of the courthouse and into a courtroom, while he was on trial in an unrelated case").

45. Huggins, $2009 \mathrm{WL} 2973044$, at $* 3$.

46. See Burton v. R.J. Reynolds Tobacco Co., 203 F.R.D. 624, 631 (D. Kan. 2001) (embracing guidance espoused in Ethicon Endo-Surgery v. U.S. Surgical Corp., 160 F.R.D. 98,99 (S.D. Ohio 1995) ("Where the objection is to irrelevant or repetitious questions, and interrogating counsel persists in such questioning after objection, opposing counsel's remedy lies in applying to the court for a protective order or sanctions ....")); Zottola v. Anesthesia Consultants of Savannah, P.C., No. 411-154, 2012 WL 6824150, at *5 (S.D. Ga. June 7, 2012) (asking questions in regard to "highly personal and sensitive matters that have no bearing on the subject matter" of the litigation); Freeman v. Schointuck, 192 F.R.D. 187, 188-90 (D. Md. 2000) ("baiting the [expert] deponent by saying she was going to 'get three strikes' and be 'out."'); In re Fletcher, 424 F.3d 783, 785 (8th Cir. 2005) (criticizing attorney for "race baiting"). 
plaintiff's "assistant" improperly trained a video camera solely on opposing counsel. ${ }^{47}$ Furthermore, the video portrayed the assistant rifling through opposing counsel's confidential notes during breaks. ${ }^{48}$ District of Kansas magistrate judge O'Hara stopped short of dismissing the case entirely, but imposed economic sanctions and prohibited the use of the depositions at trial. ${ }^{49}$ Rather than coaching the witness via speaking objections, some litigators have resorted to writing discreet messages on legal pads, ${ }^{50}$ sending text messages to the deponent, ${ }^{51}$ and tapping the deponent's feet under the table. ${ }^{52}$ The methods of discreet incivility employed by opposing counsel are only limited by the instigator's imagination. When attorneys encounter obstructionist behavior, it is important to build a record at the deposition, remind opposing counsel of the rules governing the deposition, and seek the court's assistance if it continues. ${ }^{33}$

Needlessly harsh or abusive commentary, directed at the deponent or opposing counsel, is also a common theme that the judiciary appears determined to stop. In Paramount Communications v. QVC Network, when the defending attorney, the infamous and recently deceased Texas trial lawyer, Joe Jamail, ${ }^{54}$ referred to opposing counsel as an "asshole,"

47. Leo v. Garmin Int'l, Inc., No. 09-2139-KHV, 2010 WL 1418587, at *1 (D. Kan. Jan. 7, 2010), rev'd in part, No. 09-2139-KHV, 2010 WL 1418586, at *6 (D. Kan. Apr. 7, 2010) (adopting the report and recommendation except for the proposed sanction of prohibiting the use of the depositions at trial).

48. Id. at * 1 .

49. Id. District Judge Vratil declined to accept the proposed sanction to preclude the use of the depositions, however this is likely not a result of the sanction being viewed as improper; rather, it appears that the sanction was not adopted because the non-offending party objected. See Leo, 2010 WL 1418586, at *6.

50. Tucker v. Pac. Bell Mobile Servs., 186 Cal. App. 4th 1548, 1551-57 (Cal. Ct. App. 2010). Although the court merely imposed monetary sanctions and required a different attorney to attend the re-deposition, such behavior would likely draw a more severe sanction in Kansas-primarily because the legal pad was purposefully destroyed after opposing counsel submitted a request to preserve it. $I d$.

51. Ngai v. Old Navy, No. 07-5653, 2009 WL 2391282, at *1-6 (D.N.J. July 31, 2009) (concluding that the text messages sent during the deposition were not protected by attorney client privilege, and ordering that copies be submitted to Plaintiff).

52. Halmos v. Ins. Co. of N. Am., No. 08-10084, 2011 WL 1655597, at *2 (S.D. Fla. May 2, 2011).

53. MALONE \& HOFFMAN, supra note 2, at 268-73.

54. Joe Jamail gained much of his notoriety when he won the "largest court [judgment] in history, $\$ 10.53$ billion, representing oil giant Pennzoil against rival Texaco" in 1985 . He was often referred to as the "King of Torts" and was "widely known for his sharp tongue and brash style." However, his deposition antics have been held out as examples of what not to do. Joe Palazzolo, In Remembrance: Houston's 'King of Torts' Joe Jamail, THE WALl STREET Journal (Dec. 23, 2015, 3:48 PM), http://blogs.wsj.com/law/2015/12/23/in-remembrance-houstons-king-of-torts-joe-jamail/. 
and unnecessarily interjected commentary such as "[c]ome on," "[q]uit talking," "[a]sk the question," "[n]obody wants to socialize with you," the court viewed its supervisory responsibility as requiring it to raise the lack of professionalism issue sua sponte. ${ }^{55}$ Not only does this behavior reflect poorly on lawyers, it "disserves the client because it wastes time and energy-time that is billed to the client at hundreds of dollars an hour, and energy that is better spent working on the case than working over the opponent." ${ }^{, 56}$ These techniques are viewed as a deliberate effort to disrespect the deponent and, at a minimum, would impede, delay, or frustrate the fair examination in direct violation of Federal Rule 30. ${ }^{57}$ Moreover, it is discourteous to the deponent and opposing counsel in violation of the District of Kansas Deposition Guidelines. ${ }^{58}$

Across the river, the Western District of Missouri has not promulgated deposition guidelines. Although court guidelines would be more instructive, the Western District of Missouri has "set the tone early" by including the Tenets of Professional Civility adopted by the Kansas City Metropolitan Bar Association (KCMBA) in court orders that govern discovery practice. ${ }^{59}$ Among the tenets is an instruction that "[c]ivility and professionalism among all lawyers is essential to the operation of our legal system." ${ }^{\circ 0}$ Similarly, the District of Kansas has adopted the Kansas Bar Association's Pillars of Professionalism. ${ }^{61}$

55. Paramount Commc'ns v. QVC Network, Inc., 637 A.2d 34, 52 n.23, 54 (Del. 1994). The court also noted that counsel gave improper instructions not to answer. Id. at 53. But see Saldana v. Kmart Corp., 260 F.3d 228, 237-38 (3d Cir. 2001) (reversing sanctions imposing on counsel who used the word "fuck" only four times, "pantomim[ing] a gagging gesture" during a deposition, and using the word "bullshit" on one occasion).

56. Paramount Commc'ns, 637 A.2d at 52 n.24 (quoting The Hon. Sandra Day O'Connor, Address to the American Bar Association: "Civil Justice System Improvements," 5 (Dec. 14, 1993)).

57. Huggins v. Coatesville Area Sch. Dist., No. 07-4917, 2009 WL 2973044, at *3 (E.D. Pa. Sept. 16, 2009) (resulting in economic sanctions and requiring counsel to take a CLE course in civility and professionalism); Zottola v. Anesthesia Consultants of Savannah, P.C., No. 411-154, 2012 WL 6824150, at *7 (S.D. Ga. June 7, 2012) (resulting in economic sanctions and future depositions to include video aimed at counsel); see Freeman v. Schointuck, 192 F.R.D. 187, 188-90 (D. Md. 2000) (imposing economic sanctions and requiring counsel to write a letter of apology); FED. R. CIV. P. 30(d)(2).

58. See Deposition Guidelines, supra note 11, I[ 1.

59. Ross v. Kansas City Power and Light Co., 197 F.R.D. 646, 646 (W.D. Mo. 2000) (described as the "Tenets of Professional Courtesy," however the name has been changed to "KCMBA Principles of Civility”); see Professionalism: KCMBA Principles of Civility, K.C. METRO. BAR ASS'N, https://kcmba.org/web/About_Us/Professionalism/web/KCMBA_Website/About_Us/Professionalis m.aspx hkey=62815980-4cd1-48e7-8d15-e37f8ff9f69d (last visited Mar. 31, 2016) [hereinafter Principles of Civility].

60. Principles of Civility, supra note 59.

61. United States v. Shelton, No. 14-10198, 2015 WL 7078931, at*3 n.16 (D. Kan. Nov. 30, 
Noticeably absent from the KCMBA Tenets of Professional Civility is any express instruction for counsel to practice civility towards deponents. $^{62}$ Compared to the Kansas Bar Association Pillars of Professionalism, the KCMBA civility guidelines are bare-boned. ${ }^{63}$ However, should the court order adherence to the KCMBA tenets, they at least operate as a baseline to sanction the most egregious conduct between practitioners. ${ }^{64}$ For instance, in Ross v. Kansas City Power and Light Co., the district court highlighted the boorish behavior of both counsel in a deposition, which included the deposing attorney belittling the defending attorney after objections were lodged, protracted arguments between counsel regarding finger pointing, and quarreling that deteriorated into the lawyers comparing salaries. ${ }^{65}$ Because the obstreperous behavior was on both sides of the aisle, the court imposed significant monetary sanctions against both attorneys and ordered that they submit payment to a legal services entity. ${ }^{66}$ Moreover, the court directed the attorneys to provide a copy of the sanctioning order to their clients. ${ }^{67}$ The KCMBA tenets are a good starting point, but Kansas's guidelines provide a better vehicle for federal courts to use in swiftly addressing incivility. ${ }^{68}$

2015).

62. See Principles of Civility, supra note 59.

63. Compare Principles of Civility, supra note 59, with Pillars of Professionalism, U.S. DisT. CT. FOR THE DIST. OF KAN., http://www.ksd.uscourts.gov/pillars-of-professionalism/ (last visited Mar. 31, 2016).

64. Ross, 197 F.R.D. at 646 (finding a violation of the KCMBA tenets included in the courts order after judicial recognition that the court has "witnessed few episodes which approach this case in vitriolic animus").

65. Id. at 657-58, 660; see also AKH Co. v. Universal Underwriters Ins. Co., No. 13-2003JAR-KGG, 2015 WL 141629, at*3 (D. Kan. Jan. 12, 2016) (describing counsel's behavior as "harassment of the questioner" after review of the transcript quoted counsel as saying "[w]hat are you talking about," "[b]ad question," and "[a]sk a good question").

66. Ross, 197 F.R.D. at 664 (Plaintiff was ordered to pay $\$ 21,356.25$, and defendant was ordered to pay $\$ 12,201.00$. The sanctions were suspended pending final disposition of the case.).

67. Id.

68. Compare AKH Co., 2015 WL 141629, at *3 (noting that the scheduling order mandated the application of the guidelines and imposing sanctions for violations), with Picard v. Guilford House, LLC, No. X03CV106016061S, 2014 WL 1876595, at *4 n.19, *6 (Conn. Super. Ct. Apr. 3, 2014) (noting clear ethical violations and rude behavior to opposing counsel but only citing general rules of professional courtesy and deferring sanctions to the disciplinary board); see also Paramount Commc'ns v. QVC Network, 637 A.2d 34, 55-56 (Del. 1994) (declaring that "there is no clear mechanism for this Court to deal with this matter in terms of sanctions or disciplinary remedies at this time in the context of this case" because the court suspected its remedies were limited against an attorney who defended a deposition without being admitted pro hac vice). But see Carroll v. Jaques Admiralty Law Firm, P.C., 110 F.3d 290, 292 (5th Cir. 1997) ("When a party's deplorable conduct is not effectively sanctionable pursuant to an existing rule or statute, it is appropriate for a district court to rely on its inherent power to impose sanctions."). 
Ross highlights another important component of attorney incivilitythe "reputation factor." Particularly in Kansas or the Kansas City metro, where the practicing bar is relatively small, attorneys quickly gain a reputation for conduct during litigation. Following the sanctions in Ross, one of the offending attorneys in that case (Michael Fletcher) once again engaged in incivility in an unrelated case. ${ }^{69}$ The Eighth Circuit recounted Fletcher's conduct in several cases and described his borderline racist and harassing behavior as "an over-zealous attorney who frequently resorts to unprofessional tactics in an attempt to harass, humiliate and intimidate deponents and their counsel."70 Ultimately, Fletcher's behavior landed him in disciplinary proceedings in the Western District of Missouri. ${ }^{71}$ Citing violations of the Missouri Rules of Professional Conduct, the Western District of Missouri, sitting en banc, suspended Fletcher from practice before the Western District for three years, and the Eighth Circuit affirmed. ${ }^{72}$ Zealous advocacy is not a safe harbor; rather, counsel who hide behind their "warped view of zealous advocacy" through obstructionist discovery antics will quickly earn a reputation that is difficult to escape. ${ }^{73}$ Moreover, serial ignorance of the procedural rules and guidelines governing deposition conduct can result in more severe sanctions. For instance, in Howard v. Offshore Liftboats, the Eastern District of Louisiana described an attorney's checkered past with obstreperous deposition conduct and noted that his continued violations demonstrated that the monetary sanctions have had no effect to curb his behavior. ${ }^{74}$ As a result, in addition to monetary sanctions, the court ordered that counsel not participate in any future depositions for that particular case and circulated the opinion within the district. $^{75}$ Finally, the court issued a clear warning to prevent any future conduct: "the sanction ordered... by me will be severe-in all likelihood more severe than this Court is empowered to employ.",76 These well-deserved sanctions could be devastating for a practitioner and

\footnotetext{
69. In re Fletcher, 424 F.3d 783, 785-86 (8th Cir. 2005) (describing Fletcher's behavior in the "Turner Litigation").

70. Id. at 790-91.

71. Id. at 791.

72. Id. at 791-92 (citing, in part, Mo. R. PROF'L CONDUCT 4-4.4, 8.4 ("respecting the rights of third persons" and "conduct prejudicial to the administration of justice")).

73. Howard v. Offshore Liftboats, LLC, Nos. 13-4811, 13-6407, 2015 WL 965976, at *11 (E.D. La. Mar. 4, 2015).

74. Id. at $* 9$.

75. $I d$. at $* 10$.

76. Id.
} 
serves as a useful reminder that one's reputation truly precedes you.

Similar, and possibly less discreet strategies, designed to frustrate opposing counsel also would presumably violate Kansas federal and state procedural rules. For instance, in Oleson v. Kmart Corp., the District of Kansas imposed sanctions when counsel unreasonably demanded adherence to deposition schedules that extended beyond normal business hours despite the objections of opposing counsel. ${ }^{77}$ In Stengel $v$. Kawasaki Heavy Industries, Ltd., a strategy of unnecessarily objecting to everyday terminology, compounded by statements overheard during a recess that defending counsel intended to "jerk" opposing counsel around, warranted sanctions in the Northern District of Texas for impeding the deposition. ${ }^{78}$

Obviously, sexism and racism serve no rightful purpose in any judicial proceeding. Unfortunately, behavior of this sort can sometimes be a "'dirty little secret,' which, while undoubtedly occurring on a daily basis, no one speaks about in public.,"79 A spontaneous single comment without reflection, despite violating the rules, may not be a basis to impose sanctions. ${ }^{80}$ However, repeated disparaging comments, or the use of even a single comment, violate Kansas rules, including the Kansas Rules of Professional Conduct, and may result in more serious sanctions than the typical economic penalty. ${ }^{81}$ Claypole $v$. County of Monterey is a

77. Oleson v. Kmart Corp., 175 F.R.D. 570, 573-74 (D. Kan. 1997); see also Picard v. Guilford House, LLC, No. X03CV106016061S, 2014 WL 1876595, at*4 (Conn. Super. Ct. Apr. 3, 2014) (imposing sanctions in part because counsel only reserved the deposition room until $3: 15$ and delayed informing opposing counsel); see supra Part II.A.

78. Stengel v. Kawasaki Heavy Indus., Ltd., 116 F.R.D. 263, 267-68 (N.D. Tex. 1987) (imposing economic sanctions).

79. Principe v. Assay Partners, 154 Misc. 2d 702, 706 (N.Y. Sup. Ct. 1992); see also Debra Cassens Weiss, Lawyer Threatened Opposing Counsel with Stun Gun During Deposition, Court Says in Upholding Sanction, ABA JourNAL (Dec. 15, 2015, 05:45 AM), http://www.abajournal.com/news/article/lawyer_sanctioned_for_not_becoming_of_a_woman_remar k_discovery_conduct/ (quoting female counsel who declared that sexist comments are "something that almost every woman attorney has experienced again and again over their careers," and "needs to change").

80. See Principe, 154 Misc. 2d at 707; see also Freeman v. Schointuck, 192 F.R.D. 187, 188 90 (D. Md. 2000) ("While isolated acts of discourtesy or loss of temper can be expected, even from the best of counsel, and excused by the court, systematic and deliberate abuses such as displayed by Defendants' counsel ... cannot go unsanctioned ....").

81. Compare Principe, 154 Misc. $2 \mathrm{~d}$ at 707 (noting that repeated gender biased comments of "little lady," "young girl," and "little girl" were primarily to harass or maliciously injure and imposing economic sanctions), with In re Williams, 414 N.W.2d 394, 397, 399 (Minn. 1987) (suspending counsel from practicing law for six months following a racially charged comment: "[d]on't use your little sheeny Hebrew tricks on me, Rosen."); see also Claypole v. Cty. of Monterey, No. 14-cv-02730-BLF, 2016 WL 145557, at *4-5 (N.D. Cal. Jan. 12, 2016) (imposing sanctions in response to a sexist remark: "[d]on't raise your voice at me. It's not becoming of a 
recent example of a "one-off" sexist comment that resulted in monetary sanctions. ${ }^{82}$ Citing guidelines that largely mirror the District of Kansas Deposition Guidelines, the Northern District of California sanctioned an attorney for a comment made at a contentious deposition: "Don't raise your voice at me. It's not becoming of a woman . ..." "83 The court characterized the discourteous comment as endorsing a sexist stereotype that is "all too common" and chastised counsel for offering a "halfhearted politicians apology." 84 Judicial opinions of sexist remarks against women abound, however women are not immune to sanctions for similar disparaging remarks. In Mendez v. JP Morgan Chase Bank, a female attorney was accused of ducking her head under the deposition table, examining the crotch of opposing counsel, and commenting "peanuts.", 85 Although the trial court declined to impose sanctions, probably because the female lawyer denied the accusation, the judge plainly expressed his frustration with the lack of civility and requests for him to "[b]abysit[] lawyers at a deposition." ${ }^{86}$ Citing Connecticut Rules of Professional Conduct 3.4(4) and 8.4(4), which emulate Kansas's Rules of Professional Conduct verbatim, the Superior Court of Connecticut threatened swift and severe sanctions for future disparaging conduct. ${ }^{87}$

Even when the client, rather than the lawyer, is acting in an obstreperous manner, counsel must act to mitigate the behavior in order to avoid sanctions. ${ }^{88}$ Because attorneys control the means of the litigation, counsel cannot idly "sit back, allow the deposition to proceed, and then blame the client when the deposition process breaks down." At a minimum, a lawyer's failure to intercede may violate both federal and state procedural rules, Kansas ethical rules, and Kansas federal

88. GMAC Bank v. HTFC Corp., 248 F.R.D. 182, 194-98 (E.D. Pa. 2008) (finding that counsel's failure to intercede and correct the deponent's repeated hostile, uncivil, and vulgar responses was the "functional equivalent of 'advising conduct' under Rule 37(a)(5)(A)" and violated Federal Rule 30).

89. Id. at 195; see KAN. R. PROF'L CONDUCT 1.2.
} 
deposition guidelines..$^{90}$

It is becoming more common for courts to consider the totality of the circumstances, rather than imposing the run-of-the-mill attorney fee sanctions. Even when monetary sanctions are imposed, the court may consider whether the litigator is "a man of considerable wealth" and order more severe sanctions accordingly. ${ }^{91}$ More recently, in Security National Bank of Sioux City, Iowa v. Abbott Laboratories, the Northern District of Iowa imposed an unconventional sanction that required the offending litigator to produce a training video describing the court's holding, and which "provides specific steps lawyers must take to comply with its rationale in future depositions." 92 Although the court's unique sanction was ultimately reversed on appeal for failing to give the attorney proper notice, ${ }^{93}$ it signposts the inherent power and discretion courts have when determining the proper sanction. ${ }^{94}$

\section{Extreme Incivility and Unusual Behavior}

Although most attorneys are professional and courteous when conducting depositions, some cling to the argument that their extreme incivility is justified as an obligation to represent clients vigorously, aggressively, and zealously. "To be vigorous, however, does not mean to be disruptively argumentative; to be aggressive is not a license to ignore the rules of evidence and decorum; and to be zealous is not to be uncivil." 95

90. Id. at 197-98; see KAN. R. PROF’L ConduCt 1.2; see Deposition Guidelines, supra note 11 , II 1.

91. Carroll v. Jaques Admiralty Law Firm, P.C., 110 F.3d 290, 293 (5th Cir. 1997).

92. Sec. Nat'l Bank of Sioux City, Iowa v. Abbott Labs., 299 F.R.D. 595, 596-97 (N.D. Iowa 2014), rev'd on other grounds, Sec. Nat'l Bank of Sioux City, Iowa v. Jones Day, 800 F.3d 936, 944-45 (8th Cir. 2015) (reversing because the district court failed to give sufficient notice of unusual sanction).

93. Jones Day, 800 F.3d at $944-45$. To be fair, the Eighth Circuit painted a different picture of the proceedings, noting that the defending counsel had never been sanctioned in her 31 years of practice and indicating that the trial court was unfairly criticizing counsel. During the litigation, the district court criticized counsel for failing to cite non-controlling case law and made numerous derogatory comments in regard to how "out of state large firms waste tons [of] time." Id. at 938-39. Moreover, opposing counsel never raised an objection and the judge first assumed control of the case "sixteen months after defense counsel participated in the ... depositions, one year after the fact discovery had closed, and nine months after [defendant] had moved for summary judgment based on excerpts of the depositions." Id. at 938-39, 943.

94. See Kilgore v. Acad. Ltd., 86 F. Supp. 3d 1367, 1374 (M.D. Ga. 2015) (recognizing a training video as a proper sanction for egregious conduct); Gowan v. Mid Century Ins. Co., No. 5:14-CV-05025-LLP, 2015 WL 7274448, at *4, *6 (D.S.D. Nov. 16, 2015).

95. In re Williams, 414 N.W.2d 394, 397 (Minn. 1987). 
Examples of extreme incivility during depositions shine a light on the type of behavior that would cause even a layperson to shudder. In an oft-cited example, Corsini v. U-Haul International, the Supreme Court of New York dismissed a lawsuit when plaintiff, an attorney, mimicked opposing counsel's speech pattern in a manner suggesting an ethnic slur and spewed forth a barrage of insults:

You're so scummy and so slimy and such a perversion of ethics or decency because you're such a scared little man, you're so insecure and so frightened and the only way you can impress your client is by being nasty, mean-spirited and ugly little man, and that's what you are. That's the kind of prostitution you are in. ${ }^{96}$

Berating opposing counsel is never appropriate. In Carroll v. Jaques Admiralty Law Firm, P.C., the Fifth Circuit affirmed sanctions against the appellant, a practicing attorney, for referring to opposing counsel as a "slimy son-of-a-bitch." 97 A more recent case involving a plaintiff's attorney, acting pro se, provides an example of even more extreme behavior. In Crawford v. JP Morgan Chase Bank, plaintiff filed on his own behalf numerous briefs with the court, referring to defendant as "Heavenly Father," and the trial judge as defendant's "pet dog" and "sick and demented." 98 At the deposition of plaintiff's brother, plaintiff "pointed a can of pepper spray at counsel's face from a distance of approximately three feet" while declaring "if things get out of hand, I brought what is legally pepper spray, and I will pepper spray you if you get out of hand." Im Immediately thereafter, plaintiff "produced a stun gun, pointed it at [opposing counsel's] head, and said, 'If that doesn't quell you, this is a flashlight that turns into a stun gun." 100 The court of appeals affirmed dismissal of the case, and the California bar is seeking to disbar the attorney. ${ }^{101}$ Suffice it to say, extreme incivility of this nature would fall well outside the bounds of Kansas ethical rules and deposition rules and guidelines. ${ }^{102}$

Less excessive - but equally sanctionable and possibly criminal-

\footnotetext{
96. Corsini v. U-Haul Int'1, 212 A.D.2d 288, 289-93 (N.Y. App. Div. 1995).

97. Carroll v. Jaques Admiralty Law Firm, P.C., 110 F.3d 290, 292 (5th Cir. 1997).

98. Crawford v. JP Morgan Chase Bank, N.A., 242 Cal. App. 4th 1265, 1270 (Cal. Ct. App. 2015).

99. Id.

100. Id.

101. Id. at 1275 ; Weiss, supra note 79 .

102. See KAN. R. PROF’L Conduct 3.4(4), 8.4(4); Deposition Guidelines, supra note 11, If 1; FED. R. CIV. P. 30.
} 
conduct would similarly violate Kansas rules. The method of recording a deposition must be stated in the notice of deposition, and in practice lawyers have begun to use inexpensive technology such as small video cameras to record depositions. ${ }^{103}$ Although practitioners may choose not to dispute a last-minute audio or video recording notice, secretly recording depositions is fraught with problems. For instance, in Picard v. Guilford House, LLC, plaintiff's counsel surreptitiously recorded a deposition on her iPhone, which included off-the-record conversations between defendant counsel and the deponent. ${ }^{104}$ This secret recording not only violated common sense and Rules of Professional Conduct, it was discourteous and arguably violated Federal anti-eavesdropping laws. ${ }^{105}$ The Superior Court of Connecticut imposed economic sanctions, stayed the proceedings, and forwarded the matter to disciplinary authorities. ${ }^{106}$

Kansas's deposition guidelines, Rules of Professional Conduct, and the federal and state procedural rules provide instructive bounds for counsel to operate within. Stepping outside these parameters could potentially expose practitioners to sanctions and obstruct the fact-finding that depositions are designed to yield. Litigators should keep in mind that "[c]ivility is the mark of an accomplished and superb professional, but it is even more than this. It is an end in itself. Civility has deep roots in the idea of respect for the individual." 107

\section{On-the-Record Witness Coaching-Speaking Objections and Instructions Not to Answer}

On-the-record witness coaching by lawyers via suggestive objections or instructions not to answer is increasingly soliciting the judiciary's ire. Judges are becoming increasingly aware that ignoring this common problem may "reinforce - even incentivize-obstructionist tactics." 108

103. FED. R. CIV. P. 30(b)(3)(A). Note that prior notice is required to designate another method of recording the deposition. FED. R. CIV. P. 30(b)(3)(B).

104. Picard v. Guilford House, LLC, No. X03CV106016061S, 2014 WL 1876595, at *2 (Conn. Super. Ct. Apr. 3, 2014).

105. Id. at *3-4.

106. Id. at *4 n. $19, * 9$.

107. Huggins v. Coatesville Area Sch. Dist., No. 07-4917, 2009 WL 2973044, at *4 (E.D. Pa. Sept. 16, 2009) (quoting Supreme Court Justice Anthony Kennedy's speech at the 1997 ABA Annual Meeting (July 31, 1997)).

108. Sec. Nat'l Bank of Sioux City, Iowa v. Abbott Labs., 299 F.R.D. 595, 597 (N.D. Iowa 2014), rev'd on other grounds, Sec. Nat'l Bank of Sioux City, Iowa v. Jones Day, 800 F.3d 936, 944-45 (8th Cir. 2015) (reversing because the district court failed to give sufficient notice of unusual 
The genus of sanctioning suggestive objections, and practice guidelines which seek to proactively avoid such behavior, can be traced to the oftcited 1993 opinion Hall v. Clifton Precision. ${ }^{109}$ Although most courts have declined to follow Hall's narrow off-the-record conferencing rule, the Hall "guidelines" are widely accepted and directly analogous to the District of Kansas's deposition guidelines. ${ }^{110}$ Federal Rule 30(c) is also clear in this regard. It reads in part: "An objection must be stated concisely in a nonargumentative and nonsuggestive manner. A person may instruct a deponent not to answer only when necessary to preserve a privilege, to enforce a limitation ordered by the court, or to present a motion under Rule 30(d)(3)."

In Cincinnati Insurance Co. v. Serrano, District of Kansas magistrate judge Gale provided a brief and succinct opinion about the appropriateness of speaking objections. He stated that proper objections must be timely, and "relate[] to the manner of taking the deposition, the form of a question or answer, the oath or affirmation, a party's conduct, or other matters that might have been corrected at that time." 112 Further, magistrate judge Gale analyzed the Deposition Guidelines, noting the District of Kansas promulgated them "to facilitate the efficient and fair conduct of depositions." "113 These instructive guidelines provide in part:

Objections. Objections shall be concise and shall not suggest answers to or otherwise coach the deponent. Argumentative interruptions will not be permitted. The only objections that should be asserted are those involving privilege or work product protection or some matter that maybe remedied if presented at the time, such as an objection to the form of the question or the responsiveness of the answer. Other objections shall be avoided unless the deposition is being taken for the express purpose of preserving testimony. ...

.... Directions not to answer. Counsel shall not direct or request that a deponent not answer a question, unless (1) counsel has objected to the question on the ground that the answer is protected by privilege, work product immunity, or a limitation on evidence directed by the Court; or

sanction).

109. Hall v. Clifton Precision, 150 F.R.D. 525, 530-31 (E.D. Pa. 1993) (noting that "[w]ithout guidelines on suggestive objections, the spirit of the prohibition against private conferences could be flouted by a lawyer's making of lengthy objections which contain information suggestive of an answer to a pending question" and imposing detailed guidelines for discovery depositions).

110. Compare id. at 531-32, with Deposition Guidelines, supra note 11.

111. FED. R. CIV. P. 30(c)(2).

112. Cincinnati Ins. Co. v. Serrano, No. 11-2075-JAR, 2012 WL 28071, at *4 (D. Kan. Jan. 5, 2012) (quoting FeD. R. CIV. P. 30(d)(3)(B)(i)).

113. Id. 
(2) the direction not to answer is necessary to allow a party or deponent to present a Fed. R. Civ. P. 30(d) motion to the Court. When privilege or work product immunity is asserted, the witness is nevertheless required to answer questions relevant to the existence, extent, or waiver of the privilege/immunity, such as the date of a communication, who made it, to whom it has been disclosed, and its general subject matter. ${ }^{1 \text { ? }}$

As magistrate judge Gale demonstrated in Serrano, the District of Kansas can, and will, mandate application of these guidelines. ${ }^{115}$ As a baseline, these guidelines are instructive and provide a useful tool for both practitioners and judges in assessing improper use of speaking objections and the appropriateness of instructions not to answer.

\section{Speaking Objections}

The District of Kansas's Guidelines support Federal Rule 30 and 32 and highlight some important concepts: "One is to prohibit objections, which suggest answers to or otherwise coach the witness, commonly called 'speaking objections.' The other is to make clear that objections which need not be made to preserve the objection under Rule 32, should not be made in a discovery deposition. The Guidelines also prohibit argumentative interruptions." 116

As previously mentioned, Kansas state courts have not promulgated specific practice rules or guidelines governing deposition conduct, but the Kansas Rules of Professional Conduct might be stretched to encompass improper speaking objections and provide a basis for sanctions, especially if the offending lawyer's conduct is egregious. ${ }^{117}$

\section{a. "Form" Objections}

There is not a national consensus as to whether objections to the form of a question are improper. For instance, in the Northern District of Iowa, merely stating "objection, form" is insufficient. ${ }^{118}$ Under this view

\footnotetext{
114. Deposition Guidelines, supra note 11, II 5(a), (b).

115. AKH Co. v. Universal Underwriters Ins. Co., No. 13-2003-JAR-KGG, 2016 WL 141629, at *3 (D. Kan. Jan. 12, 2016).

116. Serrano, 2012 WL 28071, at *4; Deposition Guidelines, supra note 11, II 5(a), (b).

117. KAN. R. PROF’L CONDUCT 3.4, 8.4; see also infra Part II.F.

118. Sec. Nat'l Bank of Sioux City, Iowa v. Abbott Labs., 299 F.R.D. 595, 602 (N.D. Iowa 2014) rev'd on other grounds, Sec. Nat'l Bank of Sioux City, Iowa v. Jones Day, 800 F.3d 936 , 944-45 (8th Cir. 2015) (reversing because the district court failed to give sufficient notice of unusual sanction).
} 
of Federal Rules 30 and 32, “objecting to 'form' is like objection to 'improper' - it does no more than vaguely suggest that the objector takes issue with the question."119 Courts that operate under this principle require lawyers to state the basis for their objections. ${ }^{120}$ On the other end of the spectrum, some courts stringently require counsel to merely utter the words "objection as to form," 121 "[o]bjection, form," 122 or just "objection.","

In Serrano, the District of Kansas took a more moderate approach, allowing counsel to object to form and "briefly specify the nature of the form objection (e.g. 'compound,' 'leading,' 'assumes facts not in evidence')." 124 Although not directly taking a position as to whether "objection to form" would preserve a Federal Rule 32 objection, magistrate judge Gale "expects that it would be adequate if the question's defect was in that broad category and if the deposing attorney failed to request clarification at the deposition." ${ }^{25}$ Even though magistrate judge Gale would allow a brief explanation following an objection, inserting non-descriptive efforts to coach, such as, "[t]ough for anybody to do that," 126 would be deemed sanctionable as "an inappropriate speaking objection and improper 'argumentative interruption." "127 Because the District of Kansas has not taken a definitive position as to whether a failure to specify the nature of the form objection preserves a Federal Rule 32 objection, practitioners should briefly describe the nature of the form objection but be cognizant

119. Id.

120. Id. at 602 (noting that objections should be brief, and "state in a few words the manner in which the question is defective as to form (e.g., compound, vague as to time, misstates the record, etc.)" (quoting Rakes v. Life Investors Ins. Co. of Am., No. C06-0099, 2008 WL 429060, at *5 (N.D. Iowa Feb. 14, 2008))).

121. Druck Corp. v. Macro Fund (U.S.) Ltd., No. 02 Civ. 6164, 2005 WL 1949519, at *4 (S.D.N.Y. Aug. 12, 2005).

122. Turner v. Glock, Inc., No. 1:02cv825, 2004 WL 5511620, at*1 (E.D. Tex. Mar. 29, 2004).

123. In re St. Jude Med., Inc., No. 1396, 2002 WL 1050311, at*5 (D. Minn. May 24, 2002).

124. Cincinnati Ins. Co. v. Serrano, No. 11-2075-JAR, 2012 WL 28071, at *5 (D. Kan. Jan. 5, 2012) (italics omitted). Although the District of Kansas allows counsel to object as to "leading," the court does not allow derivatives of that same objection, i.e. objection "suggestive," which are viewed as a warning to the deponent not to agree. Id. at *6.

125. Id. at *5. Although the District of Kansas has detailed guidelines, Serrano identified one gaping hole that should be addressed with specific directions on what type of form objections are proper. Id. The lack of any local rules, or specific guidelines, leads to a "damned if you do, damned if you don't" conundrum that can retroactively present defense counsel with a "Catch-22." Brief of Appellant at 41, Sec. Nat'l Bank v. Jones Day, 800 F.3d 936 (8th Cir. 2015).

126. Serrano, $2012 \mathrm{WL} 28071$, at $* 5$.

127. Id. 
of the risk such an explanation may entail.

b. Clarification Inducing and "Answer, if you know" Objections

The Serrano opinion not only analyzed form objections, but it evaluated other common speaking objections as well. According to magistrate judge Gale, objections that seek to "clarify" a question are improper. "Speculation" is an objection as to foundation "is not waived if omitted under Rule 32, and is improper under Rule 30 and the [District of Kansas] guidelines." "28 Foundation objections, at their core, are relevancy objections, and "need not be made at the time of the deposition." 129 In AKH Co. v. Universal Underwriters Insurance Co., magistrate judge Gale reiterated that relevancy objections "of all stripes are improper." 130 Similarly, "[a]n objection that a question is 'over broad" is essentially an objection that the question exceeds the scope of discovery and is inappropriate. ${ }^{131}$ This does not mean that defending counsel should sit idly by and allow interrogating counsel to harass the witness, or delve into clearly irrelevant and over broad subject matter carte blanche. The District of Kansas's Deposition Guidelines ${ }^{132}$ do not specifically address questions that exceed the scope of discovery. However, in Burton v. R.J. Reynolds Tobacco Co. ${ }^{133}$ magistrate judge O'Hara directed counsel to conduct their depositions in accordance with an "eloquent[]" Southern District of Ohio case, Ethicon Endo-Surgery v. U.S. Surgical Corp. ${ }^{134}$ In Ethicon, the court declared:

Where the objection is to irrelevant or repetitious questions, and interrogating counsel persists in such questioning after objection, opposing counsel's remedy lies in applying to the court for a protective order or sanctions; counsel does not have the right to unilaterally decide such issues by instructing the witness not to answer. interpreted, the following objections were improper relevance or foundation objections: overbroad, speculation, lack of foundation, misstates the testimony, out of context, assumes facts not in evidence, the document speaks for itself, misstates the document, improper or incomplete hypothetical, legal conclusion, improper hypothetical, calls for expert opinion." Id. at *4 n.6.

131. Serrano, $2012 \mathrm{WL} 28071$, at $* 5$.

132. Deposition Guidelines, supra note 11, If 5(a).

133. Burton v. R.J. Reynolds Tobacco Co., 203 F.R.D. 624, 631 (D. Kan. 2001).

134. Ethicon Endo-Surgery v. U.S. Surgical Corp., 160 F.R.D. 98 (S.D. Ohio 1995).

135. Id. at 99 .
} 
Counsel should assess the situation, and if:

the examination so exceeds the scope of discovery that it evidences bad faith on the part of the questioner, or results in questioning which "unreasonably annoys, embarrasses, or oppresses the deponent," counsel may object as a prerequisite (see D. Kan. Rule 37.2, requiring conference prior to motion) to bringing a motion to terminate or limit the deposition under Rule 30(d)(3). ${ }^{13}$

A District of Kansas case, Layne Christenson Co. v. Bro-Tech Corp., suggests that this standard is not easily met, and upon invoking Federal Rule 30(d)(3), attorneys should be prepared to present a motion to avoid sanctions. ${ }^{137}$

Even if certain objections fall outside the prohibited "relevancy" regime, other forms of "clarification-inducing" objections, such as "objection, vague," (disguised as a form objection) coach the witness and are a prompt that the witness should ask for clarification or refuse to answer. ${ }^{138}$ For instance, in Security National Bank of Sioux City, Iowa v. Abbott Laboratories, where defending counsel lodged no fewer than 65 "form" objections, the court described the counsel-witness duo as a "tagteam" that delivered the "one-two punch of 'objection'- 'rephrase.",139 Such objections will likely result in sanctions that include re-deposing the witness because it will be "impossible to know if [a witness's] answers emanated from her own line of reasoning or whether she adopted [the] lawyer's reasoning from listening to his objections." 140 Moreover, this type of objection is often accompanied with protracted explanatory dialogue, which is an independent basis for sanctions because it unnecessarily delays the deposition and is improper under

136. Serrano, $2012 \mathrm{WL} 28071$, at $* 5$. It does mean, however, that objections that a question is "over broad," "harassing," or "argumentative" are only appropriate in this instance. Id.

137. Layne Christenson Co. v. Bro-Tech Corp., No. 09-2381-JWL-GLR, 2011 WL 4688836, at *6 (D. Kan. Oct. 6, 2011).

138. Sec. Nat'l Bank of Sioux City, Iowa v. Abbott Labs., 299 F.R.D. 595, 604 (N.D. Iowa 2014) (describing objections of “'vague,' called for 'speculation,' were 'ambiguous,' or were 'hypothetical'" as coaching objections) rev'd on other grounds, Sec. Nat'l Bank of Sioux City, Iowa v. Jones Day, 800 F.3d 936, 944 (8th Cir. 2015) (reversing because the district court failed to give sufficient notice of unusual sanction); Serrano, 2012 WL 28071, at *5; Hall v. Clifton Precision, 150 F.R.D. 525, 530 (E.D. Pa. 1993) (quoting Committee Notes to the 1993 proposed amendments as noting "lengthy objections and colloquy, often suggest[] how the deponent should respond.").

139. Abbott Labs., 299 F.R.D. at 605 (noting that counsel's objections were merely an effort to solicit the deponents "Pavlonian response[s]").

140. Cordova v. United States, No. CIV 05-563 JB/LFG, 2006 WL 4109659, at*3 (D.N.M. July $30,2006)$. 
Federal Rule 30. ${ }^{141}$ At surface-level, these forms of witness-coaching highlight the importance of the on-the-record admonition colloquy at the commencement of depositions. Such an admonition typically places the witness on notice that it is his duty to request clarification of a question, if needed, and it serves as an important tool to remind opposing counsel that any clarification by the witness can be done at the end of interrogating attorney's questions or even on an errata sheet if necessary. $^{142}$

Instructing a witness to answer "if they know" is akin to directly instructing the witness to respond "I don't know" to the question-even if they really do know the answer. Put another way, "[w]hen a lawyer tells a witness to answer "if you know," it not-so-subtly suggests that the witness may not know the answer, inviting the witness to dodge or qualify an otherwise clear question." ${ }^{143}$ There really is no middle-ground for this form of objection, as District of Kansas magistrate judge Gale articulately phrased it in Serrano: "Instructions to a witness that they may answer a question 'if they know' or 'if they understand the question' are raw, unmitigated coaching, and are never appropriate." ${ }^{144}$ In Mazzeo v. Gibbons, a District of Nevada magistrate judge imposed sanctions for this type of instruction in a scathing opinion, which concluded:

If I was an elementary school teacher instead of a judge I would require both counsel to write the following clearly established legal rules on a blackboard 500 times: I will not make speaking, coaching, suggestive objections which violate Rule 30(c)(2)... I know that speaking objections such as "if you remember," "if you know," "don't guess," "you've answered the question," and "do you understand the question" are designed to coach the witness and are improper. ${ }^{145}$

141. Id. at 609; see FED. R. CIV. P. 30; Deposition Guidelines, supra note 11, II 5(a).

142. Serrano, $2012 \mathrm{WL} 28071$, at $* 5$; see Hall, 150 F.R.D. at 526 (examining the deposition transcript and noting that counsel admonished the deponent to "[c]ertainly ask me to clarify any questions that you do not understand").

143. Abbott Labs., 299 F.R.D. at 604.

144. Serrano, 2012 WL 28071, at *5 (noting that instructions in the same vein, such as "[i]f you know the difference between the two," are similarly sanctionable) (emphasis in original); see also Lund v. Matthews, No. 8:13CV144, 2014 WL 517569, at *5 (D. Neb. Feb. 7, 2014) (imposing sanctions where defending counsel injected commentary following his objection: "if you know," and "to the best of your ability").

145. Mazzeo v. Gibbons, No. 2:08-cv-01387-RLH-PAL, 2010 WL 3020021, at *2 (D. Nev. July 27, 2010). 


\section{Instructions Not to Answer}

Because instructing a witness not to answer a question may result in a subsequent motion to compel because it violates Federal Rule 30, counsel should use this instruction with care. Directing a "deponent not to answer a question can be even more disruptive than objections.",146 Under Federal Rule 30:

An instruction not to answer is appropriate only when necessary to preserve a privilege, to enforce a limitation ordered by the court, or to present a motion to terminate or limit a deposition being conducted in bad faith or in a manner that unreasonably annoys, embarrasses or oppresses the deponent or party. ${ }^{147}$

Although counsel may feel the urge to instruct a witness not to answer if a question has been asked and answered or it is beyond the personal knowledge of their client-unless the question satisfies the Federal Rule 30 standard - such an instruction would be improper. ${ }^{148}$ Litigators who instruct their client not to answer have the burden of proving that each instruction was rightfully asserted in later proceedings. ${ }^{149}$

An instruction not to answer based on privilege or work product immunity does not obviate the witness from answering subsequent questions regarding the "existence, extent, or waiver" of the privilege or immunity. ${ }^{150}$ Moreover, at least some courts are of the mind that private conferences, except for the purposes of determining whether a privilege should be asserted, are "not covered by the attorney-client privilege, at

146. Hall, 150 F.R.D. at 530 (quoting FED. R. CIV. P. 30 Committee Notes to the 1993 proposed amendments).

147. AKH Co. v. Universal Underwriters Ins. Co., No. 13-2003-JAR-KGG, 2016 WL 141629, at *3 (D. Kan. Jan. 12, 2016) (citing FED. R. CIV. P. 30(c)(3), 30(d)(3)); Deposition Guidelines, supra note 11, II 5(a).

148. AKH Co., $2016 \mathrm{WL} 141629$, at *3 (noting that questions counsel considered unclear or lacking foundation were not a basis for instructing the witness not to answer); Paramount Commc'ns v. QVC Network Inc., 637 A.2d 34, 52 n.3, 54 (Del. 1994).

149. Resolution Trust Corp. v. Dabney, 73 F.3d 262, 266-67 (10th Cir. 1995) (affirming sanctions where counsel could not meet his burden of proving that each instruction was protecting work product and criticizing counsel's blanket instruction not to answer).

150. See Deposition Guidelines, supra note 11, If 5(b) (noting that follow-up questions "such as the date of a communication, who made it, to whom it has been disclosed, and its general subject matter" are appropriate). 
least as to what is said by the lawyer to the witness" and are "fair game for inquiry by the deposing attorney to ascertain whether there has been any coaching and, if so, what." ${ }^{\text {151 }}$ Even when practitioners do not expressly instruct the witness not to answer, but previous objections or suggestions encourage the witness to refuse to answer questions within that category, the court may determine that counsel influenced the obstructive behavior. ${ }^{152}$ One method for circumventing improper instructions not to answer is to circle-back to the question later in the deposition, after an over-zealous attorney has had the opportunity to cool down. ${ }^{153}$ Undoubtedly, an instruction not to answer "impedes, delays or frustrates the fair examination of the deponent" and the District of Kansas or Kansas state courts should not hesitate to impose corresponding sanctions. ${ }^{154}$

Make no mistake, it is a mark of professionalism "for a lawyer zealously and firmly to protect and pursue a client's legitimate interests." answer, however, are unprofessional and detract from the fact-finding mission of depositions. Litigators should be cautioned that behavior of this sort does not advance the interest of one's client; rather, such attempts to "harass, humiliate and intimidate deponents and their counsel" represent an "over-zealous attorney" who potentially violates the rules of procedure, the ethical rules, and general principles of professionalism. $^{156}$

\section{Off-the-Record Witness Coaching-Improper Use of Conferencing to Coach a Deponent or Interrupt Proceedings}

Once the deponent is sworn in and the deposition begins, under Federal Rule 30(c), "[t]he examination and cross-examination of a deponent proceed as they would at trial under the Federal Rules of

151. Hall, 150 F.R.D. at 527, 529 n.7; see also infra Part II.D.

152. Cordova v. United States, No. CIV 05-563 JB/LFG, 2006 WL 4109659, at *5 (D.N.M. July 30, 2006)

153. MALONE \& HOFFMAN, supra note 2, at 273-76.

154. AKH Co. v. Universal Underwriters Ins. Co., No. 13-2003-JAR-KGG, 2016 WL 141629, at $* 4$ (D. Kan. Jan. 12, 2016) (imposing monetary sanctions, and requiring local counsel to be present during all future depositions in which the violating pro hac vice attorney participated); see KAN. R. PROF'L CONDUCT 3.4 (noting that a lawyer shall not "unlawfully obstruct another party's access to evidence").

155. Paramount Commc'ns v. QVC Network, 637 A.2d 34, 54 (Del. 1994).

156. In re Fletcher, 424 F.3d 783, 790-91 (8th Cir. 2005). 
Evidence."157 Importantly, Federal Rule 30(c) does not address the propriety of attorney and client consultations that typically occur during short breaks in a deposition, at lunch, overnight, or at any other time during the deposition process. Not surprisingly, section 60-230 of the Kansas statutes does not address the matter either. ${ }^{158}$

The reality is that private conferencing between a lawyer and his client is an accepted part of deposition practice, but these consultations, no matter when they occur, are rife with suspicion and potential abuse. ${ }^{159}$ Improper witness coaching frequently happens, which begs the question as to why there is no formal regulation to limit private discussions between the lawyer and his client-deponent. The short and easy answer may be that conferencing is impossible to regulate due to the practical and conventional realities of the deposition process itself. ${ }^{160}$ For instance, it is accepted practice that every lawyer confers with his client in some way and for various reasons during normal breaks taken at the deposition, like restroom or lunch breaks. Also, because of the importance of the attorney-client privilege and confidentiality, any regulation of private conversations between a lawyer and client seems antithetical to these inviolate client protections.

\section{Legitimate Reasons for Conferencing Under Federal Rule 30 and} State Deposition Rules

Notwithstanding the practical necessity for normal recesses in a deposition, a focus on Federal Rule 30(c) and the Kansas state counterpart, section 60-230(c), suggests that there are only two legitimate reasons for which a lawyer has the right to confer with his deponent-client during the deposition. The first purpose concerns the protection of a privilege, and it allows a lawyer to interrupt a deposition if necessary to confer with a client about whether such a privilege exists. ${ }^{161}$ If a privilege does exist, the lawyer can instruct his client not to answer a deposition question in order to protect the deponent from jeopardizing privileged information. ${ }^{162}$ Importantly, a lawyer does not

\footnotetext{
157. FED. R. CIV. P. 30(c).

158. See Kan. Stat. AnN. § 60-230 (Supp. 2015).

159. For comprehensive discussion of this topic, see A. Darby Dickerson, The Law and Ethics of Civil Depositions, 57 MD. L. REv. 273, 12-26 (1998).

160. Cincinnati Ins. Co. v. Serrano, No. 11-2075-JAR, 2012 WL 28071, at *6 (D. Kan. Jan. 5 ,

161. See Fed. R. Civ. P. 30(c); KAn. Stat. AnN. § 60-230(c) (2015).

162. Id.; see also supra Part II.C.1.
} 2012). 
share an attorney-client relationship with a third party deponent. ${ }^{163}$ Thus, counsel would have no legal basis to confer regarding any privileged matters with this type of independent witness.

The second legitimate reason for private conferencing is that the client may need advice about clarifying his previous deposition answers. If this is the basis for a conference, however, the lawyer is not permitted to interrupt the deposition under federal and state procedural rules; rather, counsel may later confer with his client during a normal break in the deposition. ${ }^{164}$ Again, whether a lawyer may confer with a deponent with whom he does not enjoy an attorney-client relationship even for purposes of clarifying prior deposition testimony is highly questionable, and probably improper. The basis for allowing a lawyer-client consultation to clarify prior testimony does not rise explicitly from Federal Rule 30(c) itself, but instead from the wealth of case law interpreting Federal Rule 30(e). ${ }^{165}$ As will be discussed below, subsection (e) of Federal Rule 30 allows a deponent to review his transcript once it is prepared and to make alterations to deposition testimony either in form or substance. ${ }^{166}$ The Kansas state deposition rule allows for the same. ${ }^{167}$ Though the federal courts are divided on the types and breadth of changes permitted on an errata sheet, the case law seems to be overwhelmingly consistent on one point - a deponent is permitted to alter testimony after the deposition so as to clarify deposition answers. ${ }^{168}$ In fact, under Federal Rule 30(e) and K.S.A. section 60-230, the deponent is allowed 30 days to do so. ${ }^{169}$ Thus, judicial interpretation of Federal Rule 30(e), in the context of allowing a deponent to change his testimony after the deposition, strongly supports private conferencing between a lawyer and client during normal recesses for the purpose of discussing whether clarification of prior deposition testimony is necessary and if it should be done while the deposition is happening.

Significantly, it is the private nature of off-the-record discussions that occur between a lawyer and a client, including what may well be

\footnotetext{
163. See Kan. R. Prof. Conduct Scope II 17 ("Most of the duties flowing from the clientlawyer relationship attach only after the client has requested the lawyer to render legal services and the lawyer has agreed to do so.").

164. See Fed. R. Civ. P. 30(c); Kan. Stat. AnN. § 60-230(c) (Supp. 2015).

165. See infra notes 243-45.

166. Id.

167. Kan. Stat. ANN. §60-230(c) (Supp. 2015).

168. See infra notes 243-45.

169. KAn. StAT. ANN. § 60-230(c) (2015); Fed. R. Civ. P. 30(e).
} 
innocuous chit-chat, which can foster suspicions of improper conduct, such as witness-coaching. These side-bar conversations create uncertainties in the eyes of opposing counsel because they are "known unknowns; that is to say we know there are some things we do not know" ${ }^{170}$ regarding the communication, and we suspect the lawyer may be coaching his client about how to testify in the deposition. Further, despite what little guidance Federal Rule 30 and interpretive case law provide in this regard, we do know that courts frown upon any discussions involving a lawyer reassuring his client that his testimony is helpful, or warning the client that his prior testimony has been harmful. ${ }^{171}$ Definitively, these kinds of discussions between a lawyer and a client are presumptively improper under both the rules of federal and state procedure, and may be viewed as witness-coaching. ${ }^{172}$

To be clear, the only right a deponent has to consult with counsel at a deposition exists by virtue of judicial interpretation of Federal Rule 30 (c), which allows interruption of the deposition for the lawyer and the client to confer about the existence of a privilege. ${ }^{173}$ Excluding this allowance, the rule does not speak about or authorize any other conferences between a lawyer and his client during the deposition itself, or during normal breaks. Relatedly, as a matter of federal constitutional law, it has been held that a client in a criminal case does not have a right to confer with his lawyer at all during breaks of his trial. ${ }^{174}$ In Perry $v$. Leeke, ${ }^{175}$ a state trial court order directed that a defendant could not consult with his attorney during a fifteen-minute recess that was taken while he testified in his own defense. The Supreme Court held that the state court's order did not violate the defendant's Sixth Amendment right to assistance of counsel. ${ }^{176}$ Though Perry is a criminal case, which addressed a defendant's constitutional right to counsel in a trial setting, the Perry holding has been interpreted to mean that any rules, guidelines,

170. David A. Graham, Rumsfeld's Knowns and Unknowns: The Intellectual History of a Quip, THE ATLANTIC (Mar. 27, 2014), http://www.theatlantic.com/politics/archive/2014/03/rumsfeldsknowns-and-unknowns-the-intellectual-history-of-a-quip/359719/.

171. See generally Dickerson, supra note 159, at 314-25, 314 n.196.

172. But see In re Stratosphere Corp. Sec. Litig., 182 F.R.D. 614, 621 (D. Nev. 1998) (holding that it was not improper for a lawyer to use a recess of a deposition to prepare his witness).

173. FED. R. CIV. P. 30(c). This paragraph of the rule allows a lawyer to terminate a deposition if the deposition is being conducted in "bad faith or in such manner as unreasonably to annoy, embarrass, or oppress deponent." Id.

174. See, e.g., Perry v. Leeke, 488 U.S. 272, 280 (1989).

175. Id. at 274 .

176. Id. at 280 . 
or court orders that limit a deponent's right to confer with his lawyer during breaks are permissible in a civil deposition. ${ }^{177}$

As previously discussed, in Hall v. Clifton Precision the District Court for the Eastern District of Pennsylvania addressed the precise issue of "to what extent may a lawyer confer with a client, off-the-record and outside earshot of the other lawyers, during a deposition of the client."178 In holding that the lawyer and client do not have an absolute right to confer during the deposition, the court artfully stated: "The witness comes to the deposition to testify, not to indulge in a parody of Charlie McCarthy, ${ }^{179}$ with lawyers coaching or bending the witness's words to mold a legally convenient record. It is the witness - not the lawyerwho is the witness." 180 Among the laudable points concerning deposition practice raised in $\mathrm{Hall}$, the court sought to limit opportunities in which a lawyer could coach a client in a deposition. The court stated that judges have broad discretion over managing and controlling discovery matters in a case, and it invoked Federal Rules 26(f), 30, and 37(a) to issue a blanket order prohibiting all lawyer-client conferencing in a deposition. ${ }^{181}$ The court's reason for curtailing all conferencing, even during coffee, restroom and lunch breaks, as well as overnight recesses, is because in the court's view, conferences between attorney and client "tend, at the very least, to give the appearance of obstructing the truth." "182

This portion of the Hall decision did not gain any traction, and most federal courts have since declined to follow Hall's reasoning and strict ruling despite the district court's straightforward and accurate analysis of the applicable Federal Rules. ${ }^{183}$ In fact, Hall seems to be a lone rider in its prohibition of all lawyer-client conferencing in depositions. Most federal courts, and even state courts, do not explicitly prohibit conferencing between an attorney and client at a deposition, and many

177. See Dickerson, supra note 159, at 317 n.214 (citing Aiello v. City of Wilmington, 623 F.2d 845, 858-59 (3d Cir. 1980)).

178. Hall v. Clifton Precision, 150 F.R.D. 525, 526 (E.D. Pa. 1993).

179. Charlie McCarthy was a ventriloquist dummy and not a real person. See Home Page, Charlie MCCARThY: Old Time RADIO, http://www.charliemccarthy.org/ (last visited Mar. 31, 2016).

180. Hall, 150 F.R.D. at 528 (internal footnote added).

181. Id.

182. Id

183. Acri v. Golden Triangle Mgmt. Acceptance Co., 142 PITT. LEg. J. 225 (1993). The Court of Common Pleas in Pennsylvania declined to follow Hall for many reasons, including that: (1) they provide insufficient protection for the client; (2) they can produce results that could not have been intended; and (3) they fail to recognize the proper role of counsel. Id. 
allow conferences to occur under certain conditions, like normal breaks. For example, in State ex rel. Means v. King, ${ }^{184}$ the Supreme Court of West Virginia discussed a lower court's order that prohibited plaintiff and her counsel from conferencing during the deposition breaks, as well as the overnight break. ${ }^{185}$ Apparently following the reasoning established in Hall, the trial court stated in its order that "once the Plaintiff $\mathrm{i}[\mathrm{s}]$ placed under oath for her deposition or any other sworn testimony, discussions between Plaintiff and her counsel are inappropriate." ${ }^{\prime 86}$ On appeal, the Supreme Court of Appeals of West Virginia declined to follow Hall and revised the trial court's order, holding that a lawyer may confer with his client during a normal break in a discovery deposition so long as the lawyer does not interrupt the deposition to request a conference between the question and answer for an improper purpose. ${ }^{187}$

Taking an even more liberal position regarding conferencing protocol, in In re Stratosphere Corp. Sec. Litigation, ${ }^{188}$ a magistrate judge in the U.S. District Court for the District of Nevada held that it was not improper for an attorney to confer with his client during a break in a deposition "to make sure that his ... client did not misunderstand or misinterpret [deposition] questions," nor was it improper for the lawyer to use a normal recess "to help rehabilitate the client by fulfilling [his] ethical duty to prepare a witness." 189

In 2001, in McKinley Infuser, Inc. v. Zdeb, ${ }^{190}$ the U.S. District Court for the District of Colorado addressed, among a variety of issues arising in a deposition, a lawyer's role in his client's decision to change his prior deposition testimony. While the court did not directly address improper conferencing at the deposition, it did make some key points about the common practice, distinguishing between situations where an attorney seeks to interrupt the deposition when a question is pending to coach his client from a situation where an attorney consults with his or her client on a later or earlier occasion. ${ }^{191}$ The court ruled that the truth-finding

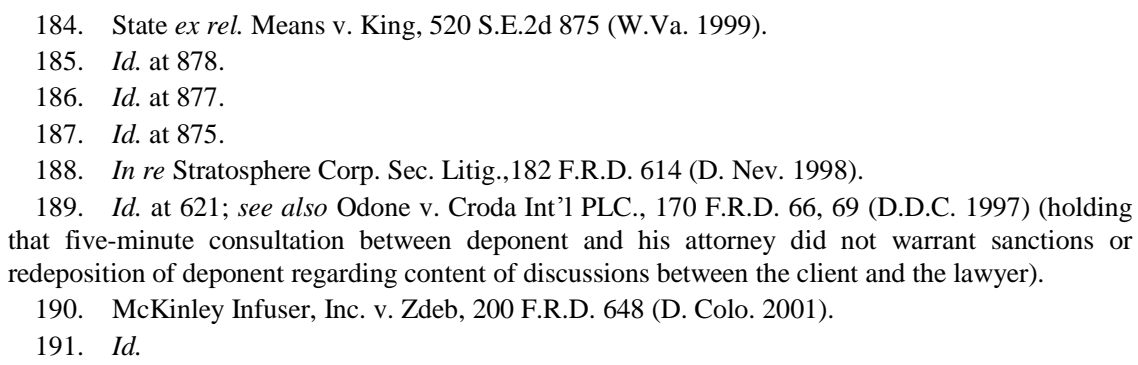


function of the deposition is adequately protected so long as there is no coaching while a question is pending and that subsequent consultations, even after a prolonged recess are permitted. ${ }^{192}$

\section{Local District Court Guidelines}

To date, due to the scant case law in this area, it is not surprising that there is no interpretive judicial decision in the Tenth Circuit or in the Kansas state practice that directly addresses the propriety of attorneyclient conferencing in a deposition. It is interesting that over 20 years ago, the court in Hall noted that "there is not a lot of caselaw" on this issue. ${ }^{193}$ That assessment remains true today. Since the few court interpretations of this topic are inconsistent, any limitations on what a lawyer and a client-deponent can discuss privately, and off-the-record, during normal breaks are not entirely clear. Moreover, any nationwide formal regulation of this type of conferencing remains unlikely. This means that practitioners are left with jurisdictional practice guidelines, standing orders, and ethical rules, to guide them in how to properly engage, if at all, in conferencing with their client during a deposition recess.

As previously mentioned, in an effort to be proactive in curbing ongoing deposition practice abuse, the District of Kansas has established Deposition Guidelines to regulate and guide attorney conduct in the area of deposition practice. ${ }^{194}$ Paragraph 5(c), "Private consultation," written in bold lettering, follows Federal Rule 30(c) and permits private conferences between a deponent and a lawyer during the actual taking of the deposition but only to determine whether a privilege or work product immunity exists. ${ }^{195}$ Any other interruptions in the deposition itself are presumptively improper. ${ }^{196}$

The guideline goes on to provide that unless the court prohibits conferencing for good cause shown, any off-the-record consultations between a lawyer and a client may be conducted during normal recesses

\footnotetext{
192. Id. at 650 .

193. Hall v. Clifton Precision, 150 F.R.D. 525, 525 (E.D. Pa. 1993).

194. See Pretrial and Trial Guidelines for Hon. Thomas Marten, U.S. DIST. CT. FOR THE DIST. OF KAN., http://www.ksd.uscourts.gov/guidelines-for-parties-and-counsel/ (last visited Mar. 31, 2016) ("Depositions. Review [FED. R. CIV. P.] 28-31 carefully. Depositions are not contests to see how much information a witness and her or his lawyer can avoid disclosing.").

195. Deposition Guidelines, supra note 11,I[ 5(c).

196. Id
} 
or adjournments. ${ }^{197}$ However, these private consultations may be subject to inquiry by deposing counsel to determine whether there has been any witness-coaching; and, if so, deposing counsel may inquire on-therecord, once the deposition recommences, what was discussed between the deponent and counsel. Lastly, the guideline provides that "[i]n such inquiry, the Court may determine whether, under applicable law, the parties to such a [sic] conferences have waived any attorney-client privilege." ${ }^{\prime 198}$ Interpreted as a whole, Paragraph 5(c) of the Deposition Guidelines helps to set the limitations and conditions of attorney-client conferencing that are permitted in Kansas federal deposition practice.

The Kansas state deposition rule, section 60-230(c) is also silent about deposition protocol concerning conferencing during a deposition, except like the federal rule, the state rule seems to allow an interruption of the deposition for purposes of allowing the lawyer and client to discuss a potential privilege issue. But unlike the federal district court Deposition Guidelines, there are no such guidelines promulgated by the Kansas Supreme Court for state practitioners. Thus, the only way a concern about improper conferencing is addressed in state practice is either through: (1) a discovery order issued by the district court under section 60-237, which can be crafted to limit or prohibit private conferences; or (2) through stipulation of the parties to use the District of Kansas Deposition Guidelines.

\section{E. Improper Use of Errata Sheets}

The use of the errata sheet to change deposition testimony is controversial in deposition practice, and the federal courts have long disagreed about the types of corrections that a deponent may make after he has had the opportunity to review the transcript and reflect on his deposition testimony. ${ }^{199}$ Under Federal Rule 30(e), the deponent is allowed to review his deposition transcript once the court reporter prepares it and he may make changes in "form or substance" to his deposition answers. ${ }^{200}$

\footnotetext{
197. Id

198. Id.

199. See A. Darby Dickerson, Deposition Dilemmas: Vexations Scheduling and Errata Sheets, 12 Geo. J. Legal Ethics 1 (Fall 1998); Devon Energy Corp. v. Westacott, No. H-09-1689, 2011 WL 1157334 (S.D. Tex. Mar. 24, 2011) (opinion provides analysis of both the narrow and broad applications of FED. R. CIV. P. 30(e)).
}

200. FED. R. Civ. P. 30(e) (emphasis added). 
According to its strict definition, the purpose of the errata sheet is to alert the court reporter to possible reporting errors in a deposition transcript. ${ }^{201}$ Its use is not meant to materially change sworn deposition testimony or to add responses that deposing counsel's questions did not elicit. ${ }^{202}$ To illustrate, a deponent's transcript may reveal a minor "form" or typographical defect, such as when the court reporter incorrectly spells the name of the city where the deponent lives, or transposes numerals of a telephone number. In instances where the transcription error is minor and insignificant, such as the examples just described, these "form" corrections do not affect the deponent's overall testimony as they relate to material facts in the case.

Any significant changes, such as contradictions to the deponent's original testimony, however, pose a curious and legitimate question about whether such dramatic changes should be permitted under Federal Rule 30(e). These types of changes are especially problematic for a party who has incurred the time and expense necessary to prepare and conduct a proper and effective fact-finding deposition, and who expects that the deponent's answers given at the deposition are truthful.

As a practical matter, it is usually a party who has been deposed by the opposing side who is likely to be later dissatisfied with his deposition testimony, either because the deponent's testimony is not as helpful as the deponent intended it to be when he gave it at the deposition, or the testimony actually harms the deponent's legal position in the case. These deponents, in particular, may be highly motivated to change their original testimony, especially when faced with a summary judgment motion filed by the opposing side.

Just how far a dissatisfied party may go to change prior testimony under Federal Rule 30(e) depends on what types of changes a court will permit. The 2010 case of Norelus v. Denny's Inc. ${ }^{203}$ is an extreme example of potential abuse in using the Federal Rule 30(e) process to change prior deposition testimony. In Denny's Inc., the plaintiff submitted a 63-page errata sheet made up of 848 material and

201. Errata Sheet, U.S. LEGAL DEFINITIONS, http://definitions.uslegal.com/e/errata-sheet/ (last visited Mar. 31, 2016).

202. Id.; but see Norelus v. Denny's Inc., 628 F.3d 1270, 1302 (11th Cir. 2010) (Tjoflat, J., dissenting) (stating that the 63-page errata sheet containing 868 changes to plaintiff's deposition testimony, "was not an errata sheet as contemplated" by the Federal Rules, but rather a "letter" from plaintiff's counsel to defense counsel).

203. Denny's Inc., 628 F.3d at 1302 (affirming sanctions against plaintiff's attorneys for abusing Federal Rule 30(e)). 
contradictory changes to her original deposition testimony. ${ }^{204}$ This case, like others, demonstrates how Federal Rule 30(e) can be abused. Currently, the federal courts are divided between a strict and broad approach to Federal Rule 30(e).

1. The Narrow Interpretation of Federal Rule 30(e)—Followed by Tenth Circuit

Despite the broad and plain language of Federal Rule 30(e), some federal courts, including the Seventh, Ninth, and Tenth Circuits, reject the notion that Federal Rule 30(e) gives a deponent carte blanche to materially change or add to deposition answers in any way that alters or contradicts the original deposition testimony without a legitimate purpose to do so. ${ }^{205}$ Courts in this group take a restrictive approach in applying Federal Rule 30(e), holding that the rule "is to be used for corrective, and not contradictory, changes."206

Notwithstanding the potentially broad and plain language of Federal Rule 30(e), the 1992 case of Greenway v. International Paper Co., ${ }^{207}$ from the Western District of Louisiana, is probably one of the earliest cases that narrowly interprets the rule, and it is this seminal case that is commonly cited by federal courts that embrace a strict application of the rule. In Greenway, an employment case, the defendant sought to "suppress and nullify" the plaintiff's attempts to make 64 separate and distinct changes to her deposition testimony. ${ }^{208}$ In the opinion, the district court contrasted the plaintiff's deposition answers with the plaintiff's corrections on the errata sheet, all of which significantly contradicted plaintiff's original testimony. ${ }^{209}$ The following examples of revised answers made by the plaintiff-deponent in Greenway are just two of many changes the court highlighted in its opinion:

As stated in the deposition:

"No, sir."

\footnotetext{
204. Id.

206. Hambleton, 397 F.3d at 1226.

207. Greenway, 144 F.R.D. at 323

208. Id

209. Id.
}

205. Greenway v. Int'l Paper Co., 144 F.R.D. 322 (W.D. La. 1992); Thorn v. Sundstrand Aerospace Corp., 207 F.3d 383 (7th Cir. 2000); Garcia v. Pueblo Country Club, 299 F.3d 1233 (10th Cir. 2002); Hambleton Bros. Lumber Co. v. Balkin Enter., 397 F.3d 1217 (9th Cir. 2005). 
Correction desired [on the errata sheet]:

"Yes, sir. For example, after I filed the quick-hour grievance in June 1990 , Jimmy retaliated against me by forbidding me from using the telephone while at work, taking any jobs without his permission and talking to any management personnel without first talking to him...,210

In yet another example, the plaintiff gave the following answer in the deposition:

"Well, it had to be over fifteen foot because ...."

Correction desired on the errata sheet:

"Well, it was approximately eight feet wide because . . .,211

In rejecting plaintiff's attempted changes, the Greenway court pointed out that in almost all of the 64 changes plaintiff made to her original answers, plaintiff's revised answers were inconsistent with her deposition testimony and were not simply making her answers: (1) more accurate and complete; or (2) for the purpose of clarification. ${ }^{212}$ The court analyzed the plaintiff's reasons for her changes, and emphasized that the "purpose of Rule 30(e) is obvious." 13 "The Rule cannot be interpreted to allow one to alter what was said under oath. If that were the case, [the deponent] could merely answer the questions with no thought at all then return home and plan artful responses. Depositions differ from interrogatories in that regard." 214 Moreover, the court chided, "[a] deposition is not a take home examination." 215

In 2000, in Thorn v. Sundstrand Aerospace Corp. ${ }^{216}$ an employment case brought under the Age Discrimination in Employment Act, the Seventh Circuit recognized that the plain language of Federal Rule 30(e) permits deposition answers to be altered in "form or substance," but the court also cited Greenway for the proposition that it is a "questionable" tactic for a deponent to substantively alter his deposition answers after

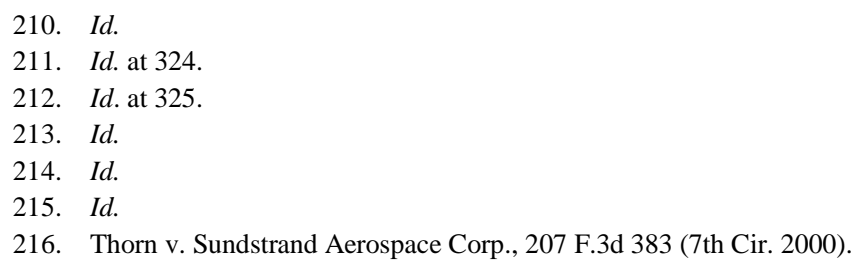


review of the transcript. ${ }^{217}$ Further, the court determined, "a change of substance which actually contradicts the transcript is impermissible unless it can plausibly be represented as the correction of an error in transcription, such as dropping a "not.", 218

The federal courts that prohibit contradictory corrections to deposition testimony have done so particularly when a party seeks to alter a deponent's answers in an attempt to defeat a summary judgment motion filed by the opposing party. This was the situation in 2002, when the Tenth Circuit decided Garcia v. Pueblo Country Club. ${ }^{219}$ In Garcia - also an employment discrimination case - the Tenth Circuit reviewed and reversed the district court's order for summary judgment in favor of the defendant. ${ }^{220}$ In arriving at its decision, the court concluded that the facts taken in the light most favorable to the plaintiff, including the defendant's reliance upon testimony "where that errata strayed substantively from the original testimony," properly stated a claim to be considered by a jury. ${ }^{221}$ Though noted in a footnote, the court commented that the Greenway court best "expressed the purpose and scope of Rule 30(e)," which is to prohibit a deponent from changing original deposition testimony in such a way that it contradicts what was first said under oath by the deponent. ${ }^{222}$ Further, the court stressed, "[w]e do not condone ... material changes to deposition testimony and certainly do not approve of the use of such altered testimony that is controverted by the original testimony." 223

In 2005, in Hambleton Bros. Lumber Co. v. Balkin Enterprises, ${ }^{224}$ the Ninth Circuit, citing both Greenway and Garcia, emphasized that any alterations to deposition answers must have a "legitimate purpose."225 The court invoked the "sham affidavit" doctrine to emphasize that "a party cannot create an issue of fact by an affidavit contradicting his prior deposition testimony." 226 In the case before it, the court went on to

217. Id. at 389 (citing Greenway, 144 F.R.D. at 322; Podell v. Citicorp Diners Club, Inc., 112 F.3d 98, 103 (2d Cir. 1997))

218. Id

219. Garcia v. Pueblo Country Club, 299 F.3d 1233 (10th Cir. 2002).

220. Id. at 1233 .

221. Id. at 1242 n.5.

222. Id.

223. Id.

224. Hambleton Bros. Lumber Co. v. Balkin Enter., 397 F.3d 1217 (9th Cir. 2005).

225. Id. at $1224-25$.

226. Id. at 1225; see also Reilly v. TXU Corp., 230 F.R.D. 486 (N.D. Tex. 2005) (analyzing the "sham affidavit" doctrine, but choosing to adopt the broad interpretation of Federal Rule 30(e)). 
critically assess the plaintiff's seemingly strategic timing in making corrections to a deponent's testimony after the defendant filed a motion for summary judgment. ${ }^{227}$ In disallowing the plaintiff's revised deposition testimony, the Ninth Circuit validated the magistrate judge's concern that the deponent's "“corrections' were not corrections at all, but rather purposeful rewrites" of deposition testimony "tailored to manufacture an issue of material fact... and to avoid a summary judgment ruling in [defendant's] favor." 228 Of important note, in Burns v. Board of County Commissioners, a case that came after Garcia, the Tenth Circuit also used the sham affidavit doctrine to evaluate whether a deponent's revisions to his original deposition testimony served a legitimate purpose. ${ }^{229}$

\section{The Broad Interpretation of Federal Rule 30(e)}

While the Tenth Circuit follows the more restrictive interpretation of Federal Rule 30(e), some federal courts rely on the broad and plain language of the rule to give deponents wide latitude to change their deposition answers. ${ }^{230}$ As early as 1981, in Lugtig v. Thomas, ${ }^{231}$ the Northern District of Illinois addressed a plaintiff's motion objecting to the 69 changes defendant-deponent made to his deposition testimony. ${ }^{232}$ The Lugtig court acknowledged that the deponent's changes were not "form" corrections, but instead "were substantive" in nature. ${ }^{233}$ In analyzing deponent's numerous changes, the court pointed out that in 30

227. Hambleton, 397 F.3d at 1225.

228. Id.; see also Combs v. Rockwell Int'l Corp., 927 F.2d 486, 488-89 (9th Cir. 1991) (noting that changes to deposition testimony were central to upcoming summary judgment proceeding, and not allowed); Burns v. Bd. of Cty. Comm'rs, 330 F.3d 1275, 1281-82 (10th Cir. 2003) (determining that plaintiff's attempts to make changes to deposition testimony must be assessed via the sham affidavit doctrine).

229. Burns, 330 F.3d at 1281-83.

230. See Podell v. Citicorp Diners Club, 112 F.3d 98 (2d Cir. 1997) (holding the district court properly considered both amended and original testimony concerning consumer's receipt of updated credit report from agency); see also EBC, Inc. v. Clark Bldg. Sys., Inc., 618 F.3d 253 (3d Cir. 2010) (holding that it is up to the discretion of the district court to allow contradictory changes on an errata sheet; however, the court should determine the appropriate remedy for such changes); Reilly, 230 F.R.D. at 491 (holding that plaintiff was permitted to correct his deposition, even though his changes altered his original testimony in substantive and contradictory ways); Eiken v. USAA Fed. Sav. Bank, 498 F. Supp. $2 d 954$ (S.D. Tex. 2007) (denying the defendant's motion to strike the plaintiff's attempts to change his deposition, because the appropriate remedy for deposition changes is impeaching the plaintiff at trial).

231. Lugtig v. Thomas, 89 F.R.D. 639 (N.D. Ill. 1981).

232. Id. at 641 .

233. Id. 
of the changes, the deponent retracted his original responses. ${ }^{234}$ In other changes, the deponent contradicted "yes" responses given at the deposition with "no" responses, and vice versa. ${ }^{235}$ Relying on the plain language of Federal Rule 30(e), the court wrote:

The language of the Rule places no limitations on the type of changes that may be made by a witness before signing his deposition.... Allowing a witness to change his deposition before trial eliminates the likelihood of deviations from the original deposition in his testimony at trial; reducing surprises at the trial through the use of Rule 30(e) is an efficient procedure. ${ }^{236}$

The rationale of the Lugtig court appears to depend not only on its reliance on the plain language of Federal Rule 30(e) but also on the principle of transparent and efficient discovery practice that Federal Rule 26 embodies. ${ }^{237}$

Like Lugtig, other federal courts have expressly relied on the plain language of Federal Rule 30(e) to permit a deponent to make any changes whatsoever to deposition testimony. ${ }^{238}$ Further, many of these courts have determined that changes made on an errata sheet are subject only to two requirements under Federal Rule 30(e). First, under Federal Rule 30(e)(1), the deponent is required make any changes within 30 days after the transcript is available. ${ }^{239}$ Second, paragraph (e)(1)(B) of the rule requires a deponent to provide reasons for any changes made to his original testimony. ${ }^{240}$ Beyond these two constraints, any retractions or additions to original deposition testimony, including contradictory changes, are allowed. ${ }^{241}$ After the deponent completes his or her changes, Federal Rule 30(e)(2) requires the court reporter to "attach" the errata sheet to the original deposition transcript. ${ }^{242}$

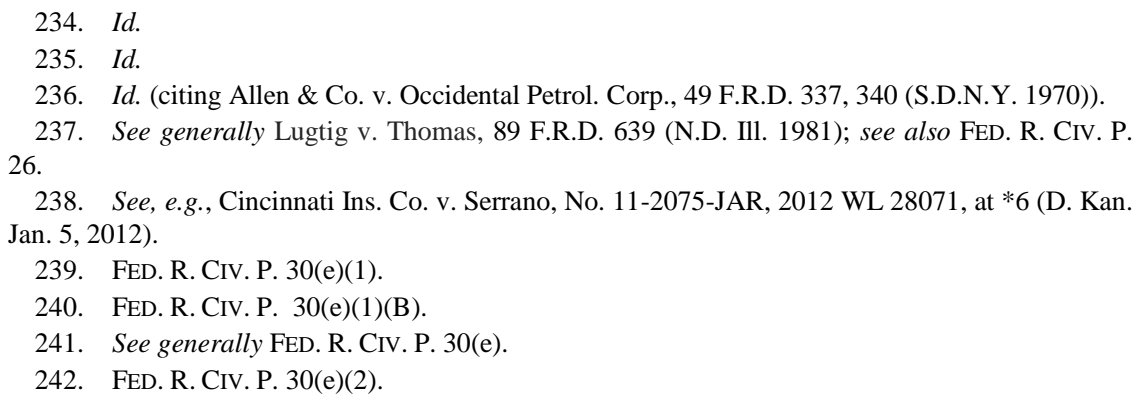




\section{Treatment of Original Deposition Testimony}

In jurisdictions, like the Seventh, Ninth, and Tenth Circuits, where courts are skeptical of, and mostly reject substantive changes or corrections to deposition answers, "only those changes which clarify the deposition, and not those which materially alter it" are allowed. ${ }^{243}$ Further, these courts have determined that any changes that contradict prior deposition testimony will not be allowed or considered as evidence. Significantly, in Greenway, the court took an extreme position when it addressed how to handle the numerous substantive and mostly contradictory changes made by the deponent. In ordering all 64 changes "deleted," the Greenway court declared "[t]he deposition... will be treated as if the plaintiff refused to sign the deposition . . .."244

As in Greenway, courts must decide how to treat original deposition testimony once it has been changed through the Federal Rule 30(e) review process. In Thorn, though the Seventh Circuit acknowledged that the language of Federal Rule 30(e) permitted the deponent to make substantive changes to his original testimony so that he could clarify "what he said to what he meant," the court cautioned that such a "tactic was foolish" because a jury could consider the deponent's original answers alongside the substantive changes made on the errata sheet. ${ }^{245}$ Referring to Federal Rule 30(e)(2), which requires all changes to be appended to the transcript, the court stressed "fortunately the rule [Federal Rule 30(e)] requires that the original transcript be retained."246 Following the same reasoning, but taking a slightly more direct approach to addressing contradictory changes made to deposition testimony, in Eicken v. USAA Federal Savings Bank, ${ }^{247}$ the District Court for the Southern District of Texas determined that "[p]laintiff's original answers will remain part of the record" and "[d]efendants" ability to use those answers to impeach Plaintiff or attack his credibility constitutes an adequate remedy." 248

243. Garcia v. Pueblo Country Club, 299 F.3d 1233, 1242 n.5 (10th Cir. 2002) (emphasis added) (citing Rios v. Bigler, 847 F. Supp. 1538, 1546-47 (D. Kan. 1994) (allowing changes to deposition testimony if the change is made to clarify original testimony, not materially alter it).

244. Greenway v. Int'l Paper Co., 144 F.R.D. 322, 325 (W.D. La. 1992).

245. Thorn v. Sundstrand Aerospace Corp., 207 F.3d 383, 389 (7th Cir. 2000).

246. Id.

247. Eicken v. USAA Fed. Sav. Bank, 498 F. Supp. 2d 954 (S.D. Tex. 2007).

248. Id. at 961 . 
4. Sufficiency of Reasons for Changes on the Errata Sheet

Federal Rule 30(e)(1)(B) requires the deponent to provide reasons for any changes he makes to a deposition transcript. ${ }^{249}$ In Duff $v$. Lobdell-Emery Manufacturing Co. ${ }^{250}$ the deponent, an employee of the defendant who terminated plaintiff's employment, supplemented his deposition testimony but failed to provide any reasons for the changes on an errata sheet as required by the rule. ${ }^{251}$ The plaintiff sought to have the deponent's revised answers, along with other evidence, stricken from the district court's consideration of the defendant's motion for summary judgment. ${ }^{252}$ In granting the plaintiff's motion to strike, the district court acknowledged that while Federal Rule 30(e) allows the deponent to make both form and substantive changes to deposition testimony, the rule is not "onerous" and "requires a statement of reasons for making them.,"253

But even when a deponent puts forth reasons for the changes to deposition answers on the errata sheet, not surprisingly, courts differ on what they find to be sufficient or adequate reasons for compliance with the rule. In Lugtig $v$. Thomas, analyzed above, the court did not question, and in fact, accepted the deponent's reasons that "he either did not know the answer, did not remember, or did not understand the question." 254 Federal Rule 30(e) merely requires the deponent to provide a reason for the changes, the court reasoned, it does not "require a judge to examine the sufficiency, reasonableness, or legitimacy of the reasons for the changes." ${ }^{255}$ Yet in Mata v. Caring for You Home Health, Inc., ${ }^{256}$ which involved an employer's attempt to defeat a plaintiff-employee's summary judgment motion in a case brought under the Fair Labor Standards Act, the District Court for the Southern District of Texas determined that the defendant-deponents gave "insufficiently vague and conclusory reasons," such as "[t]o clarify the record." 257 The Mata court interpreted Federal Rule 30(e) to require a deponent to provide more

249. See Hambleton Bros. Lumber Co. v. Balkin Enter., 397 F.3d 1217, 1224 (9th Cir. 2005) ("A statement of reasons explaining corrections is an important component of errata submitted pursuant to FRCP 30(e).”).

250. Duff v. Lobdell-Emery Mfg. Co., 926 F. Supp. 799 (N.D. Ind. 1996).

251. Id. at 804 .

252. Id. at 803 .

253. Id. at 804 .

254. Lugtig v. Thomas, 89 F.R.D. 639, 641 (N.D. Ill. 1981).

255. Id.

256. Mata v. Caring for You Home Health, Inc., 94 F. Supp. 3d 867 (S.D. Tex. 2015).

257. Id. at 872 . 
explanation about his reasons for changing his testimony in order to be in compliance. $^{258}$ It stated that a party "cannot use Rule 30(e) to make substantive, contradictory changes to deposition testimony, at least when supported only by pro forma, conclusory reasons." 259

\section{Kansas State Practice}

Traditionally, the Kansas rules of civil procedure closely follow the federal rules, and when any amendments to the federal rules are enacted, Kansas usually follows suit on those changes that are relevant to state practice. ${ }^{260}$ For the most part, discovery practice in Kansas state courts models the federal district court practice, but there are some differences unique to Kansas state deposition practice. As examples, unlike the federal rule, there is no time limit imposed on the length of a deposition, nor is there a limit to the number of depositions that a party can take in a given case under Kansas law. ${ }^{261}$ Importantly, the Kansas deposition rule, section 60-230(e), is like its counterpart, Federal Rule 30(e), because it permits a deponent to make changes to both the "form or substance" of the deponent's testimony. ${ }^{262}$ Further, the Kansas rule imposes the same time limit as the federal rule, 30 days, for the deponent to make any changes on an errata sheet, and the state rule also requires that all changes be appended to the original transcript. ${ }^{263}$ Beyond these specific examples, like its federal rule counterpart, the Kansas rule is silent about how new or revised testimony will be treated against the old testimony. $^{264}$

Unlike the controversy played out in the federal practice related to scope of changes that are allowed to be made to deposition testimony, the Kansas appellate courts have never determined the "breadth of changes" that are allowed by section $60-230(\mathrm{e}) .{ }^{265}$ Presumably, should the issue arise in state practice, the Tenth Circuit's restrictive interpretation espoused in the Garcia and Burns cases would likely carry

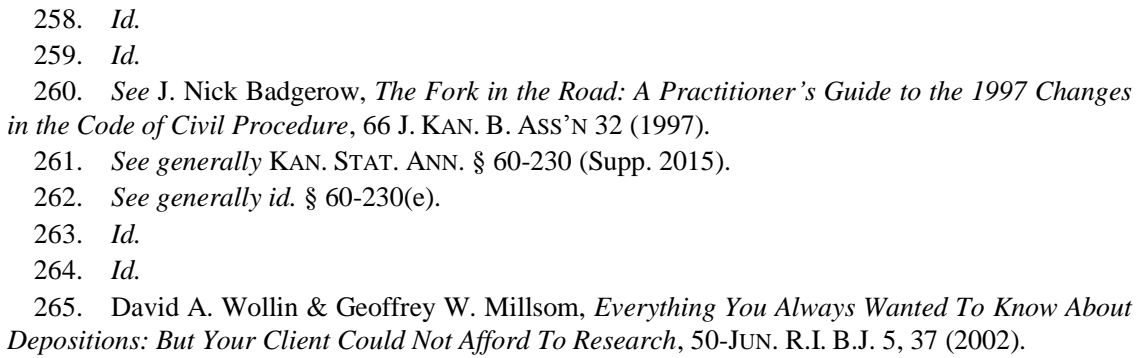


significant weight, though it is anyone's guess whether the state appellate court would follow the narrow approach when interpreting the state rule.

\section{F. Sanctions and Ethical Implications for Lawyers Practicing in Kansas}

Federal Rule 37 provides a court with a wide range of remedies to address all forms of discovery abuse. Related to depositions, the court may order sanctions if a person designated for a deposition "fails, after being served with proper notice, to appear." 266 The court may also order sanctions if: (1) a deponent fails to answer a question under Federal Rule 30 ; or (2) if the deponent provides an evasive or incomplete answer. ${ }^{267}$ The Kansas state procedural rule, section 60-237, emulates much of what Federal Rule 37 entails, though it is not as explicit or specific in its language. ${ }^{268}$ While most discovery disputes are often addressed directly in the case at hand should a court consider a Rule 37 motion, the lawyer also could be held ethically responsible under the Kansas Rules of Professional Conduct (KRPC) for any inappropriate conduct that occurs in a deposition setting. ${ }^{269}$ The myriad of rules in Kansas that are triggered for a lawyer's unethical conduct in deposition practice include: (1) 3.1-Meritorious Claims and Contentions; (2) 3.2-Expediting Litigation; (3) 3.3-Candor Toward the Tribunal; (4) 3.4-Fairness to Opposing Party and Counsel; and (5) 8.4(d)-Misconduct. ${ }^{270}$

As a general matter, under KRPC 1.2, regarding Scope of Representation, the lawyer, in consultation with the client, is responsible for making purely tactical decisions regarding a client's representation. ${ }^{271}$ Comment 1, in relevant part, states that "[a] lawyer is not required to pursue objections or employ means simply because a client may wish that the lawyer do so." 272 This comment further states: "[i]n questions of means, the lawyer should assume responsibility for technical and legal issues." ${ }^{273}$ As we have seen in this Article, it is usually the obstructionist tactics, rude or boorish behavior, or other improper conduct of the lawyer that results in discovery disputes and sanctions, all of which may be

\footnotetext{
266. FED. R. CIV. P. 37(d)(1)(A)(i).

267. See FED. R. Civ. P. 37(a)(3)-(4).

268. See generally Kan. Stat. ANN. § 60-237 (Supp. 2015).

269. See generally KAN. R. PROF'L CONDUCT 3.3.

270. Id. at 3.1, 3.2, 3.3, 3.4, 8.5(d).

271. Id. at 1.2 .

272. Id. at 1.2 , cmt. 1 .

273. Id. at 1.2 , cmt. 1 .
} 
deemed "prejudicial to the administration of justice" under KRPC 8.4(d), and which may violate other ethical rules as they pertain to deposition practice. ${ }^{274}$

1. Meritorious Claims and Contentions and Expediting Litigation

KRPC 3.1-Meritorious Claims and Contentions-provides that: "[a] lawyer shall not bring or defend a proceeding, or assert or controvert an issue therein, unless there is a basis for doing so that is not frivolous." ${ }^{275}$ Comment 1 of this rule provides that the "advocate has a duty to use legal procedure for the fullest benefit of the client's cause, but also a duty not to abuse legal procedure. The law, both procedural and substantive, establishes the limits within which an advocate may proceed." ${ }^{276}$ A related rule in the deposition context, 3.2-Expediting Litigation, expects that the lawyer "shall make reasonable efforts to expedite litigation consistent with the interests of the client." ${ }^{277}$ The rule's sole comment is illustrative in that it recognizes "[d]ilatory practices bring the administration of justice into disrepute." 278 Further, it warns that "[d]elay should not be indulged... for the purpose of frustrating an opposing party's attempt to obtain rightful redress or repose." $" 279$

Thus, the reading of both KRPC 3.1 and 3.2 suggests that gratuitous interruptions, disruptive behavior, or even improper speaking objections made by counsel during the deposition will invariably frustrate the discovery process and the right of a deposing attorney to gather information from an adverse party through an unobstructed question and answer method - the quintessential purpose of the deposition discovery tool. ${ }^{280}$

2. Candor Toward the Tribunal

Under KRPC 3.3, as it relates to deposition practice, a lawyer has two affirmative duties of candor toward the tribunal. First, under

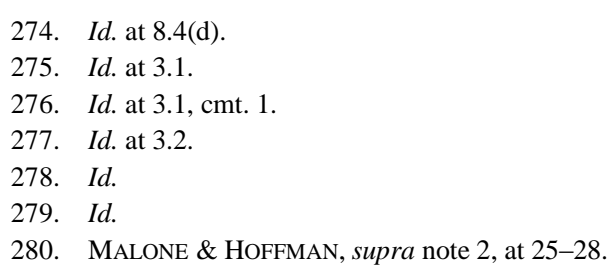


paragraph (a)(1), "a lawyer shall not knowingly make a false statement of fact ... to a tribunal or fail to correct a false statement of material fact . . . previously made to the tribunal by the lawyer."281 Importantly, comment 1 to this rule applies to a lawyer's conduct in an ancillary proceeding, such as a deposition. ${ }^{282}$ Second, paragraph (a)(3) of the rule requires a lawyer to take reasonable remedial measures if the lawyer learns that a client who is testifying in a deposition has offered false testimony. $^{283}$

Certainly, if a lawyer comes to know that his client is falsely testifying at a deposition, the lawyer must take remedial measures to correct the falsity at the deposition, if possible. Significantly, it is the deposition transcript review process that presents an opportunity for the lawyer to improperly influence the deponent regarding changes to original testimony. But no matter how unhelpful or damaging the deponent's testimony may be at the deposition or on the transcript, it is ethically impermissible for a lawyer to counsel a deponent to change testimony with the strategy and intention to provide false evidence in order to subvert important legal process.

\section{Conferencing at a Deposition}

The 2013 Kansas disciplinary case of In re Druten, ${ }^{284}$ discussed more fully below, suggests that it may necessary for an attorney to confer with his client in order to clarify testimony, or a misrepresentation of prior deposition testimony, so that any falsity that results from the deponent's testimony is corrected as soon as is practicable. ${ }^{285}$ Though the court in Druten focused on the attorney's misconduct as it related to violation of KRPC 3.4-Fairness Toward Opposing Party and Counsel-this case also makes the point that appropriate conferencing between a lawyer and client, within the parameter of the procedural rules, may prevent or serve to rectify any previous false testimony of the deponent in the deposition. $^{286}$

\footnotetext{
281. Kan. R. PROF'L Conduct 3.3.

282. Id. at 3.3 , cmt. 1 .

283. Id. at 3.3.

284. In re Druten, 301 P.3d 319 (Kan. 2013).

285. See generally id.

286. See id. at 328.
} 
4. Ethical Implications for Altering Deponent's Testimony

Because of the broad language of both the federal and state deposition rules and the controversy in the federal system regarding altered testimony when there is apparent abuse in making such changes, there is also an obvious ethical concern about the lawyer's role in the transcript review process. A prime example showing a lawyer's inappropriate conduct in submitting a false errata sheet is the case of Combs v. Rockwell International Corp. ${ }^{287}$ In Combs, the plaintiffdeponent was apparently satisfied with most of his deposition testimony, but he gave his lawyer authorization to make substantive and contradictory revisions to his deposition testimony without his review. ${ }^{288}$ The Ninth Circuit affirmed the district court's dismissal of the lawsuit as a sanction for the lawyer and his client "falsifying evidence" on the errata sheet. ${ }^{289}$ While the lawyer's misconduct in Combs was appropriately addressed directly by the court in the case itself, and with harsh consequences for the client, lawyers should consider the ethical implications for engaging in such conduct.

Presumably, federal courts like the Tenth Circuit and others, which use the narrow interpretation of Federal Rule 30(e), will be inherently suspicious about the deponent's motives for making substantive changes, especially if the changes are contradictory in nature. Probably even more concerning to courts, and even to litigants, is when a deponent makes substantive and contradictory changes that coincide with a summary judgment motion. Invariably, a deponent's decision to materially change or contradict his original deposition testimony triggers the question about the lawyer's role in the client's decision to do so. In Kansas, a lawyer could potentially violate KRCP 3.3 if he has improperly advised, encouraged, or influenced the deponent in any way to make substantive and even contradictory changes that could be viewed as "falsifying evidence."

\section{Fairness to Opposing Party and Counsel}

In addition to being truthful in a deposition, the Kansas ethical rules also require the lawyer to be fair and honest with the opposing party. KRPC 3.4(b) provides in relevant part: "[a] lawyer shall not ... falsify

\footnotetext{
287. Combs v. Rockwell Int'l Corp., 927 F.2d 486 (9th Cir. 1991).

288. Id. at 488 .

289. Id.
} 
evidence, [or] counsel or assist a witness to testify falsely." ${ }^{290}$ Comment 1 provides that the rule is meant to ensure that the "evidence in a case [is] marshalled competitively by the contending parties. Fair competition in the adversary system is secured by prohibitions against destruction or concealment of evidence, improperly influencing witnesses, [and] obstructive tactics in discovery procedure."291 KRPC 3.4 not only requires a lawyer to be honest with opposing counsel, but it also mandates that the lawyer not engage in any tactics that would obstruct discovery procedure. ${ }^{292}$ Thus, like KRPC 3.3, if a lawyer counsels a client to add or change original testimony in any way that is deemed dishonest or obstructive and which affects the opposing party in any detrimental way, the lawyer could be subject to discipline. Additionally, a practitioner who engages in incivility faces discipline because it too is an obstructive tactic." 293

As mentioned above, in Druten, the Kansas Supreme Court addressed an attorney's ethical misconduct within the context of KRPC 3.4. ${ }^{294}$ The Court concluded that the lawyer, Mr. Druten, violated numerous ethical rules, including specifically KRPC 3.4(b), when he assisted his client in testifying falsely at a deposition. ${ }^{295}$ The conduct at issue began when Mr. Druten's client, Mr. Jeffries, who was being deposed, requested a break after the deposing lawyer asked him a question that he was uncomfortable answering. ${ }^{296}$ Had Mr. Jeffries answered truthfully at the time the question was asked, the answer would have been harmful to his case. ${ }^{297}$ During the break in which the lawyer and client conferred, Mr. Druten intimated to his client that it was acceptable to lie, by saying: "[w]ell you're going to say what you want to say, so go ahead." 298 Later, in Mr. Druten's disciplinary proceeding, Mr. Jeffries was asked whether Mr. Druten advised him at any time to correct the false statement that he gave at the deposition. ${ }^{299}$ Mr. Jeffries

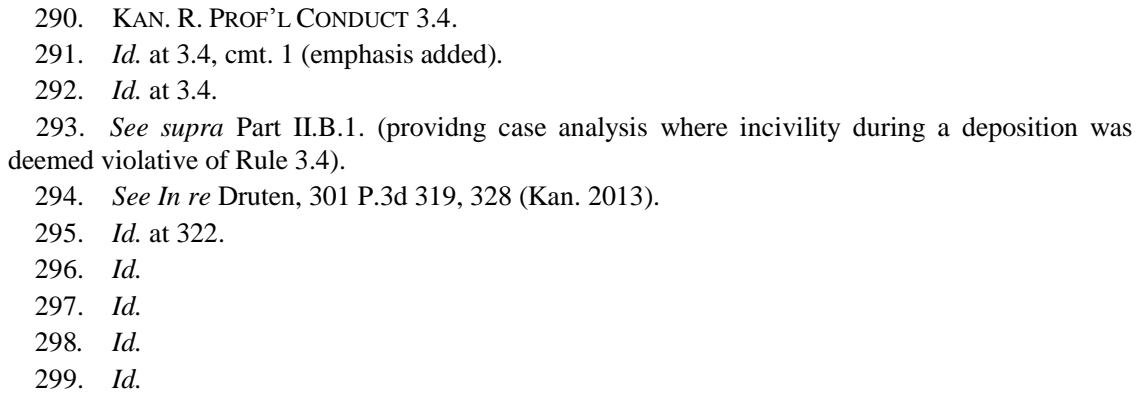


answered "no." 300 Thus, Mr. Druten's conduct in not correcting and even encouraging false testimony at the deposition was deemed unethical, and Mr. Druten was appropriately disciplined.

Finally, KRPC 8.4(d): Maintaining the Integrity of the Profession: Misconduct, provides that it is misconduct for a lawyer to "engage in conduct that is prejudicial to the administration of justice." ${ }^{301}$ This widesweeping ethics rule looks at a lawyer's inappropriate conduct broadly and focuses on whether the lawyer's misconduct in a deposition has affected legal process as a whole. ${ }^{302}$ Comment 1 to this rule is insightful because it aptly explains that it is professional misconduct for a lawyer to "knowingly assist or induce another" to violate any of the Rules of Professional Conduct. ${ }^{303}$

\section{CONCLUSION}

The proper object of any deposition is "to obtain and record the clear, truthful answers of the witness to questions which address matters within the scope of discovery." 304 This objective may be rendered merely aspirational when lawyers engage in vexatious scheduling tactics, boorish or rude behavior in the deposition, on and off-the-record witness coaching, or improper alterations of testimony by means of the errata sheet. Zealous advocacy may once have "served as the mantra for excellence," evoking the "image of a crusader for justice." 305 Today, however, a warped sense of zealous representation has made many depositions a display of gamesmanship accepted as the "routine chicanery of federal [and state] discovery practice." ${ }^{306}$ Due diligence is not de facto one-upsmanship via obstructionist deposition ploys. Rather, it is furthering the client's purpose through legal and ethical means. ${ }^{307}$

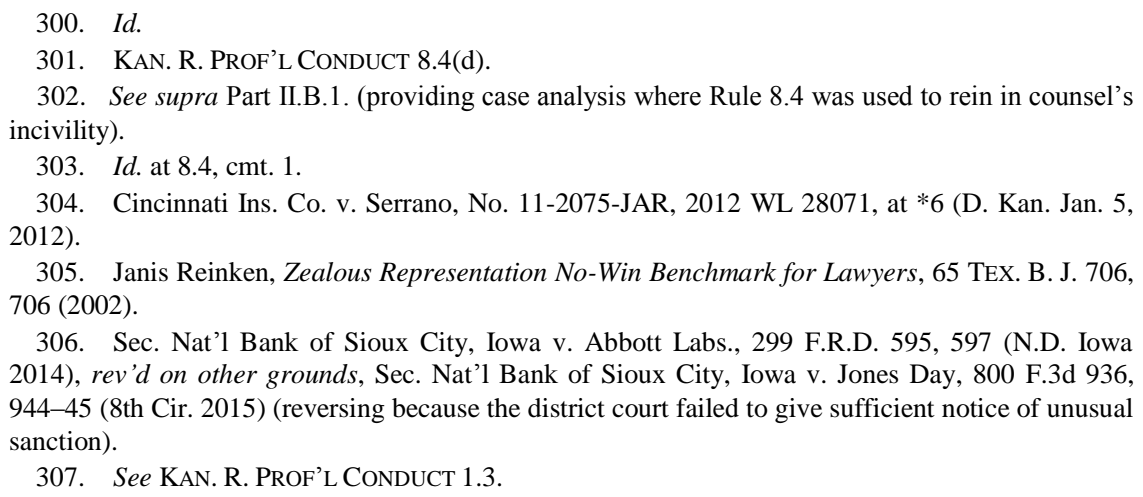


The trend of this conduct in civil litigation has reached its crescendo. ${ }^{308}$ Litigators are well-advised to take heed, and "retreat to the boundaries of the rules." $" 309$

308. See Abbott Labs., 299 F.R.D. at 596.

309. Serrano, $2012 \mathrm{WL} 28071$, at $* 15$. 